IZA DP No. 8141

Door Opener or Waste of Time? The Effects of Student Internships on Labor Market Outcomes

Nils Saniter

Thomas Siedler

April 2014 


\title{
Door Opener or Waste of Time? The Effects of Student Internships on Labor Market Outcomes
}

\author{
Nils Saniter \\ DIW Berlin \\ and IZA \\ Thomas Siedler \\ Universität Hamburg, \\ DIW Berlin, University of Essex and IZA \\ Discussion Paper No. 8141 \\ April 2014 \\ IZA \\ P.O. Box 7240 \\ 53072 Bonn \\ Germany \\ Phone: +49-228-3894-0 \\ Fax: +49-228-3894-180 \\ E-mail: iza@iza.org
}

\begin{abstract}
Any opinions expressed here are those of the author(s) and not those of IZA. Research published in this series may include views on policy, but the institute itself takes no institutional policy positions. The IZA research network is committed to the IZA Guiding Principles of Research Integrity.

The Institute for the Study of Labor (IZA) in Bonn is a local and virtual international research center and a place of communication between science, politics and business. IZA is an independent nonprofit organization supported by Deutsche Post Foundation. The center is associated with the University of Bonn and offers a stimulating research environment through its international network, workshops and conferences, data service, project support, research visits and doctoral program. IZA engages in (i) original and internationally competitive research in all fields of labor economics, (ii) development of policy concepts, and (iii) dissemination of research results and concepts to the interested public.
\end{abstract}

IZA Discussion Papers often represent preliminary work and are circulated to encourage discussion. Citation of such a paper should account for its provisional character. A revised version may be available directly from the author. 
IZA Discussion Paper No. 8141

April 2014

\section{ABSTRACT \\ Door Opener or Waste of Time? \\ The Effects of Student Internships on Labor Market Outcomes}

This paper studies the causal effect of student internship experience on labor market choices and wages later in life. We use variation in the introduction and abolishment of mandatory internships at German universities as an instrument for completing an internship while attending university. Employing longitudinal data from graduate surveys, we find positive and significant wage returns of about six percent in both OLS and IV regressions. This result is mainly driven by a higher propensity of working full-time and a lower propensity of being unemployed in the first five years after entering the labor market. Moreover, former interns pursue doctoral studies less frequently. The positive returns are particularly pronounced for individuals and areas of study that are characterized by a weak labor market orientation. Heterogeneous effects are not found across other subgroups of the population.

JEL Classification: $\quad 123, \mathrm{J01}, \mathrm{J} 31$

Keywords: internships, skill development, higher education, labor market returns, instrument variable

Corresponding author:

Nils Saniter

DIW Berlin

Mohrenstrasse 58

10117 Berlin

Germany

E-mail: nsaniter@diw.de 


\section{Introduction}

Internships have become a widespread phenomenon among university students in many countries throughout North America and Europe. Callanan and Benzing (2004), for example, argue that internships in the US have become increasingly popular as a way to bridge the transition from education to work, with three out of four college students completing an internship in 2004, compared to fewer than 40 percent of students in 1980. In Germany, 55 percent of students who are currently enrolled in a university report having completed an internship during the past twelve months (Krawietz et al., 2006). By the time students finish their studies, nearly 80 percent report at least one absence from university to complete an internship (Scarletti, 2009).

What motivates students to complete internships while enrolled at university? First and foremost, students expect internships to pay off after graduation when they enter the labor market. Indeed, when asked for their main motivation for undertaking an internship, most cited the desire to get to know the work environment and gather practical work experience. Many also hope that an internship will help them to find employment later. The desire to earn money as an intern appears to be only a secondary motivator (Krawietz et al., 2006).

The surge in popularity of internships in higher education is not only a consequence of individual choices; it is also the result of universities emphasizing the importance of internships as part of the broader educational experience. Following the policy changes implemented as part of the Bologna Reform, making graduates employable has become a central objective of higher education across Europe (Teichler, 2011). Universities have been called upon to prepare their graduates better for the transition to work by focusing on competencies that are relevant to the job market. Internships have been identified as an effective means of building these competencies (Wolter and Banscherus, 2012; Teichler, 2011). As a consequence, many universities urge students to complete internships or even make internships an integral part of the curriculum (Krawietz et al., 2006).

Internships are believed to help students build work-relevant skills, gain specific knowledge of their future occupations, develop a clearer self-concept, and confirm or redirect individual career goals (Brooks et al., 1995). Most of the skills acquired during internship are general and transferable (Busby, 2003). These attributes may then translate into various favorable outcomes for the transition into the labor market and early career success, for example, shorter job 
search duration, lower probability of unemployment, more stable job positions, better job match, greater job satisfaction, and increased earnings. However, internships also produce costs due to the investment of time, effort and sometimes even money. Interns have to accept educational opportunity costs and often enter the labor market later than non-interns. Considering the fact that most internships are poorly paid or not paid at all, it is not surprising that some debate has arisen about the potential downside effects of internships, namely the allegation that firms exploit highly qualified students as cheap workers (Wolter and Banscherus, 2012). The overall effect of internships on individual labor market outcomes is unclear, and empirical research is needed to provide a basis for sound conclusions.

In this paper, we examine the effect of student internships on subsequent labor market outcomes among university graduates in Germany. The investigation focuses on wages, but also aims at tracing the different channels by which internship experience affect wages. The key research questions are:

(a) What is the causal effect of student internships on wages later in life?

(b) To what extent do intermediary outcomes serve as transmission channels for wage returns?

Based on economic theory, we anticipate student internships to have positive wage returns. Human capital theory (Becker, 1993; Mincer, 1974) predicts that the additional knowledge, skills and competencies accumulated as an intern result in higher pay. Signaling theories point out that employers' hiring decisions are made under uncertainty since the productivity of potential workers is unknown. Job seekers may therefore use internships and positive reference letters provided to them upon completion of the internship to signal high ability, which may result in improved job matching and higher earnings (Spence, 1973; Akerlof, 1970; Schnedler, 2004). Screening theory predicts that firms use such signals to more accurately assess workers' hidden productivity (Stiglitz, 1975). Social capital theory (Bordieu, 1986; Coleman, 1988) also foresees positive labor market returns of internships because of the opportunity they provide to establish relationships with co-workers and potential employers. These social ties might lead to better jobs after graduation (Granovetter, 1995).

For the empirical investigation, we use longitudinal data from graduate surveys conducted by the German Centre for Research on Higher Education and Science Studies (DZHW) that provide 
information on students internships and income later in life. In order to account for the endogeneity of students' decisions to undertake an internship, we employ a two-stage least squares (2SLS) approach and instrument internship completion with the occurrence of mandatory internships. Exogenous variation comes from the introduction and abolishment of mandatory internships at the university level. The first-stage regressions suggest that the occurrence of mandatory internships has a large and significant impact on the likelihood of acquiring internship experience. In fact, students have a 58 percentage points higher likelihood of completing an internship during the course of their studies if the internship is mandatory. Internship experience causes wages to rise by around six percent, both in OLS and IV regressions. This result is mainly driven by a higher propensity to work full-time and a lower propensity to be unemployed during the first five years after graduating from university. Moreover, former interns begin and complete doctoral studies less frequently. The positive returns are particularly pronounced for individuals and areas of study with a weak labor market orientation. ${ }^{1}$ Across other subgroups of the population, however, we do not detect heterogeneous treatment effects.

Despite the prevalence of student internships and their significance for vocational exploration, the empirical literature on causal effects of internship experience remains scant. Several studies draw conclusions based on opinion polls among interns about the perceived benefits of their work experiences (Beck and Halim, 2008; Cook et al., 2004; Shoenfelt et al., 2013; Krawietz et al., 2006). Another strand of literature compares treatment and control groups, but does not account for potential self-selection into the treatment group. Some studies have found internships to be positively correlated with interns' self-crystallization of interests and values (Taylor, 1988) and self-efficacy (Brooks et al., 1995). Moreover, interns are reported to be more likely to adopt employer-oriented values (Pedro, 1984), to acquire job relevant competencies (Garavan and Murphy, 2001), and to possess interpersonal skills that are typically not part of the study curriculum (Crebert et al., 2004). Studies also report positive correlations of internships with shorter job search duration (Gault et al., 2000), higher job stability (Richards, 1984), more and better quality job offers (Taylor, 1988), a higher chance of choosing a career-oriented job

\footnotetext{
${ }^{1}$ At the individual level, we distinguish between students for whom labor market aspects played an important role in the choice of what to study. Further, following Scarletti (2009), we distinguish between areas of study with a strong labor market orientation (areas of study that lead to a particular profession, e.g. medicine and architecture) and areas of study with a weak labor market orientation (areas of study that teach more general skills and qualify graduates for a wide range of different jobs, e.g. history, philosophy, languages). See Table A.3 in the appendix for a complete classification of areas of studies into weak and strong labor market orientation.
} 
(Callanan and Benzing, 2004), and wage increases (Gault et al., 2000; Reimer and Schröder, 2006; Scarletti, 2009). To our knowledge the only papers that aim at estimating causal effects of internship experience are Nunley et al. (2014) and Klein and Weiss (2011). Nunley et al. (2014) conduct a résumé-audit study in the US and randomly assign three-month internship experience to fictitious job seekers. They find that applicants with internship experience receive about 14 percent more interview requests than those who were not assigned an internship. The effects are larger for non-business degree holders than for business degree holders. Klein and Weiss (2011) study wage effects of mandatory internships among university graduates in Germany. The authors employ matching estimation methods and find no positive effects on wages. Similar to our study, the authors argue that the introduction of mandatory internships is independent of unobservable characteristics. However, the scope of interpreting their results is limited. First, they use cross-sectional data and do not utilize changes in the occurrence of mandatory internships over time, which makes their identification less robust and less credible. Second, they elicit the effect of mandatory internships, not voluntary internships, and their findings are based on relative small sample sizes.

The remainder of this paper is structured as follows: Section II describes the data, and section III lays out the empirical strategy. Section IV presents the main results for the effects of internship experience on wages later in life. Section V discusses various aspects of identification. Section VI inspects whether the effects differ for various subgroups of the population. Section VII sheds light on potential intermediary outcomes that channel positive effects toward wages. Various robustness checks are presented in Section VIII. Section IX concludes.

\section{Data, Variables, and Descriptive Statistics}

We use longitudinal data from surveys of university graduates conducted by the German Centre for Research on Higher Education and Science Studies (DZHW). ${ }^{2}$ Each survey is a random sample of the student population at German universities. We employ information from three different cohorts that comprise persons who graduated in the years 2001, 2005, and 2009, respectively. For each cohort, an initial survey was conducted around one year after graduation from university. Around five years later, a follow-up survey was conducted. For the cohorts 2001

\footnotetext{
${ }^{2}$ See Rehn et al. (2011), for a thorough description of the survey and data. Recent studies that have also used DZHW data are, for example, Parey and Waldinger (2011) and Grave and Goerlitz (2012).
} 
and 2005, data are available for both waves, the initial and the follow-up survey. For the 2009 cohort, only the first wave is available. Figure 1 visualizes the timing of the data collection.

In the initial survey, students were asked whether they did a voluntary and/or mandatory internship during the course of their studies. We use this information to generate the key dummy variable for whether students did an internship and the instrument dummy variable for whether the study regulations included a mandatory internship. Further information was collected on details of the area of study and universities as well as on the graduates' opinions about their university studies. The surveys also include comprehensive demographic, socioeconomic and educational information, and information on the parental background. The main outcome variable, gross monthly wages, is self-reported for the job at the time of the interview and measured in euros adjusted to 2005 prices.

Throughout the analysis, we differentiate between two samples. We focus on Sample I, which measures wages in the second waves for the graduate cohorts 2001 and 2005, as indicated by the shaded areas in panel A of Figure 1. This sample allows us to detect effects of internships on wages five to six years after graduating. We observe that most individuals have completed the transition from university to work by this time. For wage reports from the initial survey, provided about 12 months after graduation, we suspect that some respondents have not yet entered the labor market. Some may still be looking for a job or may not be in the labor market for other reasons, for example, because they are pursuing further education. However, to use all available information from the surveys, we also work with a pooled sample, referred to as Sample II. The composition of this sample is depicted in panel B of Figure 1. It comprises all available waves for the three graduate cohorts. This sample helps to increase the precision of the estimates, which will become particularly relevant when studying heterogeneous effects in section VI. We borrow the idea of pooling the data from Parey and Waldinger (2011).

A typical feature of some university subjects and degrees is that they imply an obligatory second phase of education. For example, prospective teachers take a first state exam upon completing their university studies and then have to complete a 1.5 year practical training phase in the classroom before taking a second state exam, which then enables them to work as a teacher. Similar obligatory second educational phases of varying duration exist for lawyers, clerics and medical doctors. During this period, individuals are outside the regular labor market. For this reason, we exclude all individuals from our sample who finished university with a state 
exam (lawyers, clerics, pharmacists, teachers, and physicians) or reported having to complete an obligatory second phase of education. Furthermore, we exclude graduates who finished university with a bachelor's degree. ${ }^{3}$ Bachelor's degrees imply a shorter duration of study than other university degrees (Diplom, Magister, Master) and are less accepted by employers in Germany. Finally, we only keep observations in the estimation samples that have non-missing values for all relevant variables. This results in a sample size of 6,424 graduates for Sample I and 19,218 observations for Sample II.

Tables 1 and 2 report means for the two samples, differentiated by graduation cohort and internship experience. The numbers in column 1 in Table 1, for example, show that in Sample $I$ the average year of birth is 1976, 54 percent are female, around one in three graduates completed an apprenticeship before studying, and the final high school grade is 2.2 (on a scale 1-5 with 1 signifying "excellent" and 5 "failing"). Further, many students come from highly educated families, with 36 percent of mothers and 49 percent of fathers having graduated from an upper secondary school. Five to six years after graduating from university, 88 percent of the respondents are employed, 85 percent are employed full-time, and 70 percent have a permanent position. With respect to the main outcome variable - monthly wages - the unconditional means show that students with internship experience have slightly higher mean values than their fellow graduates.

\footnotetext{
${ }^{3}$ Bachelor graduates were only interviewed in 2009.
} 


\section{Estimation Method}

To estimate the effect of internship experience on labor market outcomes we use a 2SLS setup and instrument internship experience with the presence of mandatory internships. The two main equations are:

$$
\begin{aligned}
\log (\text { Wage })= & \beta_{0}+\beta_{1} \text { Internship }+\beta_{2} \text { Female }+\beta_{3} \text { GradCohort }+\beta_{4} \text { BIRTHYEAR }+ \\
& \beta_{5} \text { AREA }+\beta_{6} U N I V E R S I T Y+X \gamma+\epsilon \\
\text { Internship }= & \alpha_{0}+\alpha_{1} \text { Mandatory }+\alpha_{2} \text { Female }+\alpha_{3} \text { GradCohort }+\alpha_{4} \text { BIRTHYEAR+ } \\
& \alpha_{5} \text { AREA }+\alpha_{6} U N I V E R S I T Y+X \gamma+\varepsilon
\end{aligned}
$$

where $\log ($ Wage $)$ is the logarithm of wages, BIRTHYEAR is a $22 \times 1$ vector that comprises indicators for year of birth, $A R E A$ is a $53 \times 1$ vector that comprises fixed effects for students' area of study, and UNIVERSITY is a $262 \times 1$ vector that comprises university fixed effects. ${ }^{4}$ Female and GradCohort are dummy variables indicating gender and the graduation cohort. ${ }^{5}$ Depending on the particular specification, the vector $X$ contains different sets of additional explanatory variables. In equation (1), the variable Internship equals one if the student did an internship while studying, and zero otherwise. In the first-stage equation (2), the dichotomous variable Mandatory equals one if an internship was mandatory during the course of studies, and zero otherwise.

We present results for two different specifications. In our baseline model, we control for individuals' year of birth fixed effects, area of study, and university fixed effects, a female and graduation cohort dummy, as well as a dummy variable for graduating from a university of applied sciences. We call this the parsimonious model. In the second specification-called the full model — we add several predetermined variables that are likely to be good proxy variables for students' intelligence, ability, and labor market orientation. We control for students' final high school grade (high school grade), whether they completed an apprenticeship before studying (apprenticeship), the self-reported influence of labor market aspects on their choice of what

\footnotetext{
${ }^{4}$ Note that for $A R E A$, the data only allow us to observe the areas of study, which are referred to as Studienbereiche in the nomenclature of the Federal Statistical Office (2012), but not the exact subject. For example, we can observe whether someone studied Romance philology, but not whether the subject was French, Italian, Spanish, or Portuguese.

${ }^{5}$ When estimating the above regressions for Sample II, we control for two dummy variables for graduate cohorts, as the sample includes graduates from the 2001, 2005, and 2009 cohorts.
} 
career to pursue and thus what to study at the university (labor market orientation), as well as a full set of dummy variables for mother's and father's highest general educational degree (four groups each). ${ }^{6}$

\section{Results}

The OLS and IV results for equation (1) are presented in Table 3. Each column shows the estimated coefficients and standard errors from a different regression. The first four columns present results for wages measured about five years after graduating from university (Sample I), and columns 5-8 show the estimates from pooled regressions that also include wages measured one year after graduating from university (Sample II). In the Sample I regressions, standard errors are clustered at the university level. In the Sample II regressions, standard errors are clustered at the individual level. ${ }^{7}$ In the robustness section VIII, we also present results when clustering at the level of the area of study or the departments, where departments are defined as unique combinations of area of study and university.

All regressions in Table 3 show a positive and significant relationship between internship experience and wages. The OLS coefficients for both samples suggest that a student who gained labor market experience through an internship during the course of his or her studies has around 6 percent higher wages later in life. The coefficients are statistically significant at the 1 percent level. Importantly, the IV estimates also point to a positive and significant relationship between internship experience and graduates' labor market wages, with estimated effects of around six percent. The comparison of OLS and IV estimates from Sample I reveals a small upward bias in the OLS regressions, which is potentially due to ability bias. However, the estimates based on Sample II do not suggest an upward bias in the OLS regressions. Taken as a whole, the estimates in Table 3 suggest positive wage returns of student internship experience of around six percent.

Table 3 also shows the estimated effects for other selected explanatory variables. Female graduates have around 17-20 percent lower wages than male graduates. These results are broadly

\footnotetext{
${ }^{6}$ Mincer type wage equations typically control for age and age ${ }^{2}$ to proxy work experience. Age variables have been omitted from the baseline specification because they are likely to be outcome variables themselves. This is because internship experience might delay labor market entry due to the extra time working rather than attending university. We experimented with the inclusion of age variables and found that this leaves our results unchanged.

${ }^{7}$ While the former accounts for suspected error correlation at the level of universities, the latter accounts for the fact that for many individuals in Sample II, we use repeated observations at the individual level, one from the initial survey and one from the follow-up survey.
} 
consistent with previous findings for Germany (Machin and Puhani, 2003; Leuze and Strauß, 2009). Moreover, the estimates for the variable apprenticeship reveals that graduates who completed an apprenticeship before studying have around five to eight percent higher wages. In the IV regressions, the magnitude of the estimate is quite similar to the effect of internship experience. Note, however, that apprenticeships last on average around three years, whereas student internships last on average twelve weeks (Scarletti, 2009). A comparison of these two estimates underlines the economic relevance of the positive wage returns of internships.

First-stage results based on equation (2) are presented in Table 4. We again report estimates for the parsimonious and full model for Samples I and II, respectively. As expected, the estimated coefficient for the instrumental variable Mandatory is always positive and precisely estimated at the 1 percent significance level. The estimates suggest that a compulsory student internship increases the likelihood of internship experience by around 58 percentage points. The corresponding F-statistics of about 38 and 70 also point toward a strong first-stage relationship. In line with the summary statistics in Tables 1 and 2, the first-stage estimates show a negative relationship between studying at a university of applied sciences and having completed an apprenticeship before studying and the likelihood of doing an internship during the course of studies. $^{8}$

\section{Aspects of Identification}

This section provides arguments and evidence that support the credibility of our results for causal interpretation. Four aspects are addressed: (1) differences in the quality of universities and study programs; (2) variation over time in requirements to complete an internship; (3) the impact of potential confounders, that is, simultaneity in the introduction or abolishment of mandatory internships with other changes at the level of university or the area of study; and (4) the possibility of self-selection into study programs with mandatory internships.

\section{Differences in Quality of Universities and Study Programs}

One potential concern may be that the quality and reputation of the university and/or the study program are correlated with the availability of mandatory university-organized internships, and

\footnotetext{
${ }^{8}$ Students at universities of applied sciences are less likely to complete an internship while being enrolled at university, but are much more likely to do an "practical semester" during the course of their studies than students at university. In the robustness section below, we will return to this issue in more detail.
} 
with graduates' labor market outcomes later in life. If good universities offer, on average, more programs with mandatory internships and if their graduates are also more successful in finding high quality jobs, then instrumental variable estimates can be upward biased. To account for this, the regressions control for a maximum set of university and area of study fixed effects. As a result, differences between universities and differences between area of study at a given university are controlled for. To further mitigate this concern, one robustness check in Section VIII involves the inclusion of 1,149 dummy variables that represent unique combinations of university and area of study (i.e. departments). Another sensitivity analysis includes dummies for combinations of area of study and type of university (e.g. university or university of applied sciences). The estimates from both robustness exercises are not significantly different from the main results in Table 3. Differences in the quality of universities and their areas of study therefore do not pose a threat to our identification strategy.

\section{Variation in Mandatory Internships over Time}

A key premise for identification is that there is variation in the presence of mandatory internships that is exogenous to individual unobserved characteristics. In this section, we shed some light on the introduction and abolishment of mandatory internships across cohorts, universities, and areas of study, which is the main source of variation.

The data allow us to identify the existence of mandatory internships for individuals who report having chosen a certain subject in a certain area of study at a certain university. We also know the cohort to which they belong. However, single observations do not reveal whether there was a change in the occurrence of mandatory internships for earlier or later cohorts. In order to capture potential status changes, we therefore refer to departments as the smallest institutional units available, where departments are defined to be unique combinations of universities and areas of study. We then calculate the proportion of students in a department reporting a mandatory internship, separately for each cohort. If, from one cohort to the next, the majority of reports in one department change from the non-existence to the existence of mandatory internship, then we consider this department to have introduced mandatory internships. If the change occurs in reverse direction, then we think of the department as having abolished mandatory internships. In the same fashion, this procedure also allows us to detect departments that have not changed their status. Table 5 sorts department and observations 
from Sample I into distinct groups that result from the outlined procedure. As the reports within the combinations of department $\times$ cohort (cells hereafter) are rarely univocal, we have to define the (non-)existence of mandatory internships along the lines of thresholds. The 50/50 threshold defines cells as having mandatory internships if more than half of all graduates report that an internship was mandatory, and zero otherwise. Alternative thresholds are 60/40 and $70 / 30$, which are more restrictive in the sense that they determine the status of cells only if the majority is more pronounced. That is, assignment is only established if the proportions exceed the 60 (70) percent level or stay below the 40 (30) percent level. When choosing the optimal threshold, one therefore faces a trade-off between maintaining a high number of observations (best 50/50) and precisely assigning departments into the different groups (best 70/30). ${ }^{9}$

Columns 1 and 2 of Table 5 define the different groups. Missing cells or cells which are ambiguous in the sense that they do not exceed the thresholds in either direction, are marked by a dash. Since not all departments are included in both surveys from 2001 and 2005, we have an unbalanced panel data set. Sample I comprises 262 different universities and 53 different areas of study, yielding a total of 1,149 departments. For the 50/50 threshold, column 3 shows that there are 64 departments that introduced mandatory internships from 2001 to 2005. Conversely, 53 departments abolished mandatory internships. The corresponding numbers of students in columns 4 and 5 suggest that around 11 percent (721 out of 6,424), of all observations belong to a department in which variation occurred over time. If we disregard the departments in rows 5-9, for which there is uncertainty about status changes, this share increases to 61 percent $(232+140+122+227=721$ out of 1,176$)$ indicating that more than half of the departments might have changed the status of mandatory internships between the 2001 and 2005 cohorts. Hence, there is considerable variation in mandatory internships at the department level over time that contributes to the identification of our IV estimates.

\footnotetext{
${ }^{9}$ We are aware that this approach involves some measurement error as we only observe departments and not their actual study regulations, which would be more precise. However, we believe that this is the best we can do to evaluate the variation in mandatory internships over time, since no such information at the department level is available from external data sources. In the robustness section, we use all three thresholds to generate alternative instrumental variables to evaluate the robustness of the main findings. However, none of the alternative instruments captures the exposure to mandatory internships as precisely as students' own reports.
} 


\section{Impact of Potential Confounders}

If the introduction or abolishment of mandatory internships coincided with other changes at the area of study or university level that could in turn affect wages, this would pose a major threat to our identification strategy. For instance, if the introduction of mandatory internships coincided with improvements in career counseling, estimates of internship experience would likely be upward biased. In order to assess the influence of such potential confounders, we make use of items in the questionnaires that elicit the respondent's evaluation of various aspects of studying. More specifically, we examine twelve different quality indicators of the area of study and/or university that may have an independent effect on wages, thereby potentially biasing the main results.

The twelve indicators cover the following four areas: (1) overall quality of education, (2) educational media and infrastructure, (3) training, and (4) career counseling. Respondents can rate items in each of the categories on a five-point scale, from "very bad" (1) to "very good" (5). ${ }^{10}$ In difference-in-difference regressions based on Sample I, we test whether changes in the quality indicators coincide with the introduction and abolishment of mandatory internships. We estimate regressions of the form

$$
E_{d u Q u a l}=\alpha_{0}+\alpha_{1} 2005 \text { cohort }+\alpha_{2} \text { Treat }+\alpha_{3} \text { Treat } * 2005 \text { cohort }+X \gamma+\epsilon,
$$

where the outcome variable $E d u Q u a l_{j}$ measures the $j$ th variable of educational quality with $j=1, \ldots, 12$ and Treat indicating the binary treatments of either introducing or abolishing mandatory internships in a person's department. ${ }^{11}$ For the alternative treatments -introduction and abolishment — we run two separate regressions. The DiD estimate of interest is parameter $\hat{\alpha}_{3}$. For each variant of equation (3), two different specifications are estimated. The first specification estimates simple DiD regressions without controlling for additional explanatory variables, i.e. removing $X$ from the equation. The second specification controls for a rich set of background

\footnotetext{
${ }^{10}$ Figure A.1 in the appendix displays the distribution of the twelve variables. The figure shows that there are considerable differences in how graduates evaluate the quality of their studies. For example, around 50 percent of the graduates rate the structure of the degree program and the modernity of methods taught as very good or good (panel A). In contrast, fewer than 15 percent of graduates assign this positive rating to the provision of career orientation (panel C).

${ }^{11}$ In line with the methodology described above, we use the 50/50 threshold for identifying changes in the occurrence of mandatory internships at the level of departments. In unreported regressions, we also use the $60 / 40$ and 70/30 thresholds. The DiD estimates based on these alternative thresholds yield similar results and are available from the authors upon request.
} 
variables that are identical to the full model (cf. Table 3). Furthermore, both specifications are estimated based on two different samples. In the first sample, the comparison group consists of graduates from departments that experienced no change in mandatory internship over time. In the second sample, the comparison group is restricted and depends on the treatment: for Treat being the introduction (abolishment) of mandatory internships, the control group consists of graduates from departments that never (always) had mandatory internships.

Table 6 reports the estimates of $\alpha_{3}$ from equation (3) for the treatment of introducing mandatory internships. Each estimated coefficient and standard error in parenthesis comes from a different regression. Positive coefficients imply that the introduction coincides with improvements in the quality indicators, and negative coefficients indicate a deterioration. None of the estimated DiD effects in Table 6 is statistically significant at the 5 percent level. The only estimates that are statistically significant at the 10 percent level are for the outcome variable Writing skills training. However, the estimated coefficients suggest that the introduction of mandatory internships coincides with a deterioration - rather than an improvement - in writing skills training. If writing skills training is a determinant of graduates' wages later in life, our results in Table 3 may be downward biased, not upward biased.

Table 7 reports the DiD estimates from equation (3) for the treatment of abolishing mandatory internships. Consistent with the results in Table 6 , there is no statistical evidence that the abolishment coincides with deteriorations in the quality indicators. ${ }^{12}$ All in all, we interpret the findings of Tables 6 and 7 as evidence that the introduction and abolishment of mandatory internship does not coincide with other study related changes.

\section{Self-Selection into Mandatory Internships}

Our identification approach crucially hinges on the assumption that individuals do not select themselves systematically into study programs with mandatory internships based on unobservable characteristics. Put differently, the instrument must provide variation that is exogenous given the control variables. This assumption would be violated if, for example, more ambitious students were more likely to choose subjects with mandatory internships, and if they were also more successful in the labor market later in life. Moreover, ambition would have to be an omitted

\footnotetext{
${ }^{12}$ In unreported regressions, we also estimated the DiD models with dichotomous outcome variables equal to one if the graduates said that the particular aspect of study quality was very good or good, and zero otherwise. The results from these linear probability regressions are in line with the estimates in Tables 6 and 7 , respectively.
} 
variable that is not sufficiently captured by observables such as high school degree, labor market orientation and parents' educational background, all of which are included in the full model specification. We believe that it is very unlikely that students choose their subjects and universities based on whether internships are mandatory. Instead, we believe the quality and reputation of the study programs and universities are the most important choice determinants (Parey and Waldinger, 2011). Proximity to the nearest university is also an important factor (Spiess and Wrohlich, 2010). Several German newspapers such as Handelsblatt and Die Zeit regularly publish university rankings by subjects and institutions, and this information is widely circulated. However, none of these published rankings includes information on internships. Moreover, gathering information from university websites as to whether or not internships are mandatory is rather difficult. We therefore believe that students' self-selection into mandatory internships is unlikely to bias the present estimates.

In order to support these arguments with tentative empirical evidence, we refer to the methodology of the DiD estimates above and investigate whether the composition of students' background characteristics changed as departments introduced and abolished mandatory internships. In the spirit of equation (3), we regress both treatments on the following predetermined variables: mother's and father's highest school degree (one if Abitur, zero otherwise), student's labor market orientation when starting university studies, and final high school grade. Table 8 presents the results based on the 50/50 threshold for the introduction (panel A) and abolishment (panel B) of mandatory internships. The linear probability estimates in both panels show that these variables are not significantly correlated with the treatments. ${ }^{13}$ This strengthens our argument that self-selection is unlikely to be a concern.

\section{Heterogeneous Effects}

This section studies the heterogeneity of treatment effects across subgroups of the population. We know from previous studies that, for example, college degree returns are higher for females than for males (Jacobson et al., 2005; Jepsen et al., 2014). In order to assess whether such differences also exist for internship experience, panel A of Table 9 reports the impact of internship experience separately for women and men. To investigate whether estimations differ signifi-

\footnotetext{
${ }^{13}$ When using the alternative thresholds $60 / 40$ and $70 / 30$ we find similar results. See Tables A.1 and A.2 in the appendix.
} 
cantly between groups, also the relevant p-values from interacted models are reported. Panel B investigates heterogeneity in treatment effects by parents' education. The sample is divided by whether or not one of the parents has an upper secondary school degree. Students with highly educated parents might benefit from their social networks, irrespective of their own labor market experience. Hence, student internship might be more rewarding for students without these intergenerational networks. In panel $\mathrm{C}$ in Table 9, separate effects are estimated for graduates by their final high school grade, since students with high grades are likely to have other unobservable characteristics (e.g., high motivation, intelligence, social skills) that might make them benefit more from an internship than students with lower grades. Further, due to their abilities, they might be more likely to participate in an internship of high quality and prestige, an aspect that we cannot observe. The estimates in panel D show heterogeneity of treatment effects across students' labor market orientation. Students for whom labor market aspects played a critical role in their choice of what to study might be more ambitious and motivated during their internships than students with lower levels of labor market orientation, potentially leading to higher returns. Alternatively, internships might be particularly beneficial for students who have not given much thought to labor market aspects. An internship experience might help them to gain a clearer self-concept and develop better career plans. Finally, panel E in Table 9 reports separate treatment effects according to whether the area of study has a strong or weak labor market orientation. Following Scarletti (2009), we sort graduates' areas of study into those with a strong labor market orientation when they lead to a particular profession. Examples are medicine and architecture, since nearly all medical students become doctors and most students of architecture work as architects later in life. In contrast, study areas with a weak labor market orientation do not necessarily lead to a particular profession. They teach more general skills that qualify graduates for a wide range of different jobs. Examples are history, philosophy, and languages. ${ }^{14}$

The estimates in panels A, B and C in Table 9 do not point toward heterogeneous treatment effects of internship experience by gender, parental background, or high school performance. In contrast, the point estimates in panels D and E suggest that internships are particularly beneficial for students with lower levels of labor market orientation. For example, the IV estimates in

\footnotetext{
${ }^{14}$ Compare Table A.3 in the appendix for a complete classification of areas of study into weak and strong labor market orientation.
} 
Panel D, column 5 (Sample II) report returns of around 10 percent for students, for whom labor market aspects did not play an important role in their choice of what to study compared to only 1 percent for those who took labor market aspects strongly into consideration. The difference of 9 percentage points is statistically significant from zero at the 10 percent level, as indicated by the p-value of 0.066 from the interacted model. In line with this finding, the estimates in panel $\mathrm{E}$ in Table 9 also point toward higher returns of internship experience for graduates in areas of study with a weak labor market orientation. For Sample II, the difference is again significant at the 10 percent level. We conclude that those who benefit most from internship experience are individuals with a weaker labor market orientation. One explanation for this is that internships help students to develop a better understanding of their future occupation and a clearer concept of their own preferences. Moreover, for graduates in subjects with a weak labor market orientation, internships can help to establish contacts with potential employers, which may facilitate the screening of candidates when the subject of studies is not a strong signal. ${ }^{15}$

\section{Transmission Mechanisms}

In this section, we examine potential transmission mechanisms by which internships may affect wages. Table 10 presents OLS and IV estimates of the effect of internship experience on various measures of job matching, type of employment, occupation, job position, and doctoral studies, all of which are potential intermediary variables for positive effects on wages later in life.

Panel A in Table 10 sheds light on the match between a person's academic qualification and the job requirements. Respondents are asked: "Does your job match your academic qualifications in terms of: (1) your occupational status, (2) the level of tasks assigned to you, (3) your degree?" Answers can be given on a five-point scale, ranging from 1 "No, not at all" to 5 "Yes, definitely". We generate dichotomous outcome measures for job matching which are equal to one if graduates tick a four or five on the five-point scale, and zero otherwise. ${ }^{16}$ The summary statistics in Table 1 reveal that - using these measures - 73 percent of graduates say that their job matches their academic qualification in terms of the occupational status, 72 percent report a match in

\footnotetext{
${ }^{15}$ In unreported regressions, we also distinguished between students who graduated from a university versus a university of applied sciences. Studies at universities of applied sciences are more practically oriented and the treatment effect of internship experience might therefore differ by the type of university degree. The regression results did not point toward heterogeneous effects.

${ }^{16}$ In unreported regressions, we also estimated the effects on the original five-point scale variables. The estimates were in line with those reported here.
} 
terms of the level of tasks assigned to them, and 66 percent in terms of academic degree. The match appears to be slightly better for former interns. Indeed, OLS estimates in Panel A in Table 10 suggest that a student internship experience during studies is associated with a 3-4 percentage point increase in the probability of reporting a good or very good job match in terms of occupational status and in terms of the level of tasks assigned to them. However, the corresponding IV estimates are considerably lower in magnitude and not statistically different from zero at conventional significance levels. This is also true for the third job matching outcome variable. ${ }^{17}$ The IV estimates for employment outcomes in panel B in Table 10 suggest that internship experience increases the probability of being in full-time employment at the time of the interview by around four percentage points, but has no positive effect on the likelihood of having a permanent position. Further, panel $\mathrm{C}$ and $\mathrm{D}$ show that there are no positive effects on the likelihood of working as a civil servant, being employed, being self-employed, or being in middle or upper management position. However, the results in panel E suggest that part of the positive impact of internship experience may stem from a lower likelihood of continuing higher education with doctoral studies: the IV results indicate that internship experience decreases the probability of starting and completing doctoral studies by about 4 and 3 percentage points, respectively.

Another topic of interest is how internship experience affects these transmission variables over time, specifically during the first years after graduating from university. We use calendar information in the surveys to construct binary activity indicators for every month during the first five years after graduating from university. Monthly information is available for employment, unemployment, full-time employment, and doctoral studies. Figure 2 graphically displays the estimated coefficients of internship experience for these activities from OLS and IV regressions. The vertical bars represent the 95 percent confidence intervals. Panel A in Figure 2 displays the effects of internship experience on the probability to be employed. While there are no significant effects during the first two years, later years exhibit positive coefficients, though significant at the five percent level only during the third year. Panel B reports estimates on the likelihood to be unemployed. The graph reveals that internship experience decreases the risk of

\footnotetext{
${ }^{17}$ Graduates were also interviewed about how satisfied they are in various domains of their current job (the content of their work, the working conditions, and whether the job is in line with their qualifications). We also investigated the effects of internship experience on these items of satisfaction. Consistent with the estimates in Table 10, none of the estimated IV coefficients pointed toward an improvement in job match quality.
} 
being unemployed during the first year. However, in later years, this effect levels off to nearly zero and becomes insignificant in most regressions. Panel $\mathrm{C}$ in Figure 2 shows the results for being in full-time employment. This indicator is only defined for employed individuals in the respective month. The coefficients are positive and mostly significant, confirming the findings from Table 10. Finally, panel D reports for every month whether the individual is currently enrolled in doctoral studies. In line with the above findings, internship experience decreases the likelihood of engaging in doctoral studies over the whole time span.

Overall, the findings in Table 10 and Figure 2 suggest that the positive effect of internship experience on wages likely stems from graduates' educational and employment choices. Indeed, when plugging the variables that we identified as being intermediary outcomes-fulltime employment, started and completed $\mathrm{PhD}$, months in employment and unemployment-as additional controls into the wage equation (1), the premium of internship experience shrinks considerably. Table 11 shows that estimating this over-specified model cuts the OLS coefficient roughly by half. Similarly, the IV coefficient is reduced to a value near 2 percent and no longer retains its significance. This confirms our belief that most of the wage effect is driven by these intermediary variables. ${ }^{18}$

\section{Robustness Checks}

In this section, we first discuss alternative instrumental variable estimations to evaluate the robustness of the main findings in Table 3. Thereafter, we present sensitivity checks with respect to sample attrition, clustering, time-trends, and additional explanatory variables.

Table 12 presents results from five alternative instrumental variable estimations, together with the corresponding first-stage estimates and F-statistics. The first alternative instrument $I V_{50}$ is an indicator variable equal to one if the majority of students of a certain graduate cohort and department (i.e. area of study at a specific university) say that an internship was mandatory, and zero otherwise. This instrument measures the strength of students' exposure to mandatory internships at the departmental level. ${ }^{19}$ Similarly, the instruments $I V_{60}$ and $I V_{70}$ are dichotomous variables equal to one if the majority of students (e.g., 60 or 70 percent,

\footnotetext{
${ }^{18}$ Note that the variable "Ever started a $\mathrm{PhD}$ " has a negative effect on wages, because it captures all individuals who have dropped out of doctoral studies or who have not finished them by the time of the interview. In contrast, successful PhDs can expect wage gains as indicated by the variable "Completed PhD".

${ }^{19}$ For a similar approach, see Parey and Waldinger, 2011, who use exposure to scholarships of the ERASMUS program to instrument study stays abroad.
} 
respectively) report that a student internship was mandatory, and zero if fewer than 40 or 30 percent, respectively, do so. ${ }^{20}$ The fourth instrument $I V_{\text {Ratio }}$ measures the proportion of graduates for whom an internship was mandatory. Similar to the first three instruments, it is defined for cells that are constructed from combinations of cohorts $\times$ departments. The fifth instrument $I V_{\text {Ratio }_{2}}$ also measures the proportion of graduates with a mandatory internship, but it is based on cells that are constructed from combinations of university starting years $\times$ departments. Using the year when individuals entered university rather than the graduation year may improve the precision of the instrument in the sense that it is more likely to capture different study regulations. In most cases, study regulations are imposed on students at the beginning of their studies.

Panel A in Table 12 shows the results of alternative IV regressions based on Sample I. The point estimates suggest positive returns on internship experience of between 6-11 percent. However, only the estimates in columns 1 and 5 are precisely estimated at the 10 percent and 5 percent significance levels, respectively. Note that the first-stage relationships are less precisely estimated than in our main instrumental variable regression, with the F-statistics ranging between 15 and 24. The IV estimates for the larger Sample II are displayed in panel B. They suggest positive wage returns of internship experience of around 9-13 percent. With the exception of the coefficient in column 1 , the point estimates are statistically significant at the 5 percent level. Taken together, the estimates in Table 12 strongly support the main findings in Table 3, suggesting that student internships have a positive causal impact on wages later in life.

Table 13 reports the results of further sensitivity analyses based on the full model specification similar to the regressions in Table 3. First, we consider the fact that certain departments might differ in educational quality, connections to firms, or degree of support provided to students in finding high-quality jobs. To control for these potential differences, panel A in Table 13 reports the estimates when controlling for a maximum set of department fixed effects. These fixed effects are added to the full model specification, which already comprises area of study and university fixed effects. Hence, there might be the risk that this model is overspecified. It turns out that the coefficients for internship experience decrease, suggesting positive returns of around 4-5 percent.

\footnotetext{
${ }^{20}$ Note that areas of study in which $40-60$ percent (or 30-70 percent) of graduates say that an internship was mandatory are excluded from the regressions, resulting in smaller sample sizes in columns 2 and 3 in Table 12.
} 
Second, the regressions always control for whether students studied at a university or a university of applied sciences. However, there might be differences in labor market returns for the same area of study across the two types of universities. For example, studying economics might differ in terms of quality or labor market returns between universities and universities of applied sciences. To address this concern, the regressions in panel B in Table 13 additionally include fixed effects for combinations of area of study and type of university. Reassuringly, the estimates do not change notably.

Third, there is the risk that the returns on internship experience are confounded by other forms of practical work experience. For instance, 38 percent of graduates say that they completed a "practical semester", that is, a semester spent working and not completing coursework (86 percent of whom are graduates of a university of applied sciences), and 48 percent report paid employment during the course of their studies that was related to their degree. Moreover, the requirement to complete an internship might affect whether students pursue other forms of work experience, which might be substitutes or complements for internships. The regressions in panel C therefore control for whether graduates completed a "practical semester", and the estimates in panel D in Table 13 also include a dummy variable for whether graduates worked during the course of their studies. The point estimates for internship experience remain largely unaffected.

Fourth, panel E reports the results when clustering at the area of study level, rather than at the university level. The standard errors are nearly identical to those in Table 3 and the overall conclusions do not change. Finally, sample attrition might be a problem, as only 41 percent of individuals participating in the initial survey were also interviewed in the follow-up survey. To address this concern, panel $\mathrm{F}$ reports estimates of internship experiences on wages only measured at the time of the initial survey, i.e., around one year after graduation. The estimates also point toward positive effects of internship experience on wages of around six percent. We therefore argue that the main findings are unlikely to be biased by selected sample attrition.

\section{Conclusions}

This study provides new evidence on the causal effects of student internships on wages for university graduates. It also investigates potential mechanisms, such as job matching and graduates' educational and occupational choices, which are likely to influence, or to be correlated with, wages later in life. The estimates from instrumental variable regressions suggest that work 
experience gained through student internships increases wages by around six percent five years after graduation. The positive returns are likely to be driven by a higher propensity to work full-time, and a lower likelihood to continue education by pursuing doctoral studies. Further, the empirical findings suggest that graduates who completed an internship face a lower risk of unemployment during the first years of their careers. However, there is little evidence that internships improve job matching, or impact on graduates' occupational choices. The positive returns are similar in magnitude for female and male graduates, and for students from universities and universities of applied science. There is also no empirical evidence of heterogeneous effects by students' socio-economic background and ability, proxied by their parents' educational attainments and students' average final high school grade, respectively. However, we do find significant differences in treatment effects with respect to the labor market orientation of students and areas of study. Highest returns are estimated for a weak labor market orientation, which is in line with the notion of internships serving as a means of vocational exploration and screening.

The present findings are of interest for university students, policy makers, and educators alike. Student internship experience can be regarded as a "door opener" to the labor market. In recent decades, much debate in higher education has centered on what are believed to be contradictory goals: on the one hand, the aim of incorporating labor market demands into the curricula of higher educational institutions and on the other hand, that of guaranteeing freedom and independence in academic research and teaching. Our study suggests that university education - combined with practical learning through internships - might be one way of bringing these two aspects together. 


\section{References}

Akerlof, G. A. (1970). The Market for Lemons: Quality Uncertainty and the Market Mechanism. The Quarterly Journal of Economics 84(3), 488-500.

Beck, J. E. and H. Halim (2008). Undergraduate Internships in Accounting: What and How do Singapore Interns Learn from Experience? Accounting Education 17(2), 151-172.

Becker, G. S. (1993). Human Capital: A Theoretical and Empirical Analysis, with Special Reference to Education (3 ed.). Chicago: The University of Chicago Press.

Bordieu, P. (1986). Forms of Capital. In J. G. Richardson (Ed.), Handbook of Theory and Research for the Sociology of Education, pp. 241-260. New York: Greenwood Press.

Brooks, L., A. Cornelius, E. Greenfield, and R. Joseph (1995). The Relation of Career-Related Work or Internship Experiences to the Career Development of College Seniors. Journal of Vocational Behavior 46(3), 332-349.

Busby, G. (2003). Tourism Degree Internships: A Longitudinal Study. Journal of Vocational Education 8 Training 55(3), 319-334.

Callanan, G. and C. Benzing (2004). Assessing the Role of Internships in the Career-Oriented Employment of Graduating College Students. Education + Training 46(2), 82-89.

Coleman, J. S. (1988). Social Capital in the Creation of Human Capital. American Journal of Sociology 94, S95-S120.

Cook, S., R. S. Parker, and C. E. Pettijohn (2004). The Perceptions of Interns: A Longitudinal Case Study. The Journal of Education for Business 79, 179-185.

Crebert, G., M. Bates, B. Bell, C.-J. Patrick, and V. Cragnolini (2004). Developing Generic Skills at University, During Work Placement and in Employment: Graduates' Perceptions. Higher Education Research \&5 Development 23(2), 147-165.

Garavan, T. N. and C. Murphy (2001). The Co-operative Education Process and Organisational Socialisation: A Qualitative Study of Student Perceptions of its Effectiveness. Education + Training 43(6), 281-302. 
Gault, J., J. Redington, and T. Schlager (2000). Undergraduate Business Internships and Career Success: Are They Related? Journal of Marketing Education 22(1), 45-53.

Granovetter, M. S. (1995). Getting a Job: A Study of Contacts and Careers (2 ed.). University of Chicago Press.

Grave, B. S. and K. Goerlitz (2012). Wage differentials by field of study - the case of German university graduates. Education Economics 20(3), 284-302.

Jacobson, L., R. LaLonde, and D. G. Sullivan (2005). Estimating the Returns to Community College Schooling for Displaced Workers. Journal of Econometrics 125(1-2), 271-304.

Jepsen, C., K. Troske, and P. Coomes (2014). The Labor-Market Returns to Community College Degrees, Diplomas, and Certificates. Journal of Labor Economics 32(1), 95-121.

Klein, M. and F. Weiss (2011). Is Forcing Them Worth the Effort? Benefits of Mandatory Internships for Graduates from Diverse Family Backgrounds at Labour Market Entry. Studies in Higher Education 36(8), 969-987.

Krawietz, M., P. Müßig-Trapp, and J. Willige (2006). HISBUS Blitzbefragung: Praktika im Studium. Kurzbericht Nr. 13. Hochschul-Informationssystem.

Leuze, K. and S. Strauß (2009). Lohnungleichheiten zwischen Akademikerinnen und Akademikern: Der Einfluss von fachlicher Spezialisierung, frauendominierten Fächern und beruflicher Segregation: [Wage Inequality between Male and Female University Graduates: The Influence of Occupational Specialization, Female-Dominated Subjects and Occupational Segregation]. Zeitschrift für Soziologie 38(4), 262-281.

Machin, S. and P. A. Puhani (2003). Subject of Degree and the Gender Wage Differential: Evidence from the UK and Germany. Economics Letters 79(3), 393-400.

Mincer, J. (1974). Schooling, Experience, and Earnings. New York: Columbia University Press.

Nunley, J. M., A. Pugh, N. Romero, and R. A. Seals (2014). College Major, Internship Experience, and Employment Opportunities: Estimates from a Résumé Audit. Auburn University Working Paper 2014-03. 
Parey, M. and F. Waldinger (2011). Studying Abroad and the Effect on International Labour Market Mobility: Evidence from the Introduction of ERASMUS. The Economic Journal 121(551), 194-222.

Pedro, J. D. (1984). Induction into the Workplace: The Impact of Internships. Journal of Vocational Behavior 25(1), 80-95.

Rehn, T., G. Brandt, G. Fabian, and K. Briedis (2011). Hochschulabschlüsse im Umbruch: Studium und Übergang von Absolventinnen und Absolventen reformierter und traditioneller Studiengänge des Jahrgangs 2009, Volume 17 of HIS: Forum Hochschule.

Reimer, D. and J. Schröder (2006). Tracing the Gender Wage Gap: Income Differences Between Male and Female University Graduates in Germany. Zeitschrift für ArbeitsmarktForschung Journal for Labour Market Research 39(2), 235-253.

Richards, E. W. (1984). Undergraduate Preparation and Early Career Outcomes: A Study of Recent College Graduates. Journal of Vocational Behavior 24(3), 279-304.

Scarletti, A. (2009). Die Bedeutung von Praktika und studentischen Erwerbstätigkeiten für den Berufseinstieg: Dissertation, Volume 77 of Studien zur Hochschulforschung. München.

Schnedler, W. (2004). The Value of Signals in Hidden Action Models: Concepts, Application, and Empirical Evidence. Contributions to Economics. Heidelberg: Physica-Verlag.

Shoenfelt, E. L., N. J. Stone, and J. L. Kottke (2013). Internships: An Established Mechanism for Increasing Employability. Industrial and Organizational Psychology 6(1), 24-27.

Spence, M. (1973). Job Market Signaling. The Quarterly Journal of Economics 87(3), 355.

Spiess, K. C. and K. Wrohlich (2010). Does Distance Determine who Attends a University in Germany? Economics of Education Review 29(3), 470-479.

Statistisches Bundesamt (2012). Studierende an Hochschulen, Fächersystematik: Wintersemester 2006/207. Fachserie 11 Reihe 4.1.

Stiglitz, J. E. (1975). The Theory of Screening, Education, and the Distribution of Income. The American Economic Review 65(3), 283-300. 
Taylor, M. S. (1988). Effects of College Internships on Individual Participants. Journal of Applied Psychology 73(3), 393-401.

Teichler, U. (2011). Bologna - Motor or Stumbling Block for the Mobility and Employability of Graduates? In H. Schomburg and U. Teichler (Eds.), Employability and Mobility of Bachelor Graduates in Europe, pp. 3-41. Rotterdam: SensePublishers.

Wolter, A. and U. Banscherus (2012). Praxisbezug und Beschäftigungsfähigkeit im BolognaProzess - A Never Ending Story? In W. Schubarth, K. Speck, A. Seidel, C. Gottmann, C. Kamm, and M. Krohn (Eds.), Studium nach Bologna: Praxisbezüge stärken?!, pp. 21-36. Springer Fachmedien Wiesbaden. 
Figures and Tables

Figure 1: DZHW Panel Survey of Graduates

(A) Sample I

\begin{tabular}{|c|c|c|c|c|c|c|c|c|c|c|c|}
\hline \multirow{2}{*}{$\begin{array}{c}\text { Graduate } \\
\text { cohort }\end{array}$} & \multicolumn{11}{|c|}{ Year } \\
\hline & 01 & 02 & 03 & 04 & 05 & 06 & 07 & 08 & 09 & 10 & 11 \\
\hline 2001 & $\begin{array}{l}\frac{E}{\sqrt{0}} \\
\underset{x}{x}\end{array}$ & 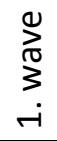 & & & & 2. & ave & & & & \\
\hline 2005 & & & & & $\begin{array}{l}\frac{\varepsilon}{\sqrt{x}} \\
\text { ய }\end{array}$ & $\begin{array}{l}\stackrel{0}{0} \\
3 \\
\text { i }\end{array}$ & & & & 2. & \\
\hline 2009 & & & & & & & & & $\begin{array}{l}\frac{\varepsilon}{\sqrt{0}} \\
\text { ய }\end{array}$ & $\begin{array}{l}\int_{\pi}^{0} \\
\sum_{3}^{2} \\
-i\end{array}$ & \\
\hline
\end{tabular}

(B) Sample II

\begin{tabular}{|c|c|c|c|c|c|c|c|c|c|c|c|}
\hline \multirow{2}{*}{$\begin{array}{c}\text { Graduate } \\
\text { cohort }\end{array}$} & \multicolumn{11}{|c|}{ Year } \\
\hline & 01 & 02 & 03 & 04 & 05 & 06 & 07 & 08 & 09 & 10 & 11 \\
\hline 2001 & $\begin{array}{l}\frac{E}{\pi} \\
\underset{x}{x}\end{array}$ & $\begin{array}{l}0 \\
\sum_{0}^{0} \\
3 \\
-i\end{array}$ & & & & 2. & ave & & & & \\
\hline 2005 & & & & & $\begin{array}{l}\frac{\varepsilon}{\sqrt{x}} \\
\underset{\sim}{x}\end{array}$ & $\begin{array}{l}\overbrace{\pi}^{0} \\
3 \\
-i\end{array}$ & & & & 2. $v$ & \\
\hline 2009 & & & & & & & & & $\begin{array}{l}\frac{\varepsilon}{\sqrt{0}} \\
\underset{x}{\Psi}\end{array}$ & $\begin{array}{l}\stackrel{0}{\pi} \\
3 \\
-i\end{array}$ & \\
\hline
\end{tabular}

Note: Adopted from Rehn et al. (2011), p. 367. This study employs data from graduate surveys conducted by the Centre for Research on Higher Education and Science Studies. It includes random samples of university graduates who passed their last exam in 2001, 2005, and 2009. For the cohorts 2001 and 2005, we utilize an initial survey one year after graduation (first wave) and a follow-up survey about five years after graduation (second wave). For the cohort 2009, only the first wave is available. For the analysis, we use two different combinations of the data, as indicated by the shaded areas: Sample I comprises only the second wave observations of the graduate cohorts 2001 and 2005. Sample II is a pooled sample. It comprises the second-wave observations and all first-wave observations of the cohorts 2001, 2005, and 2009. 


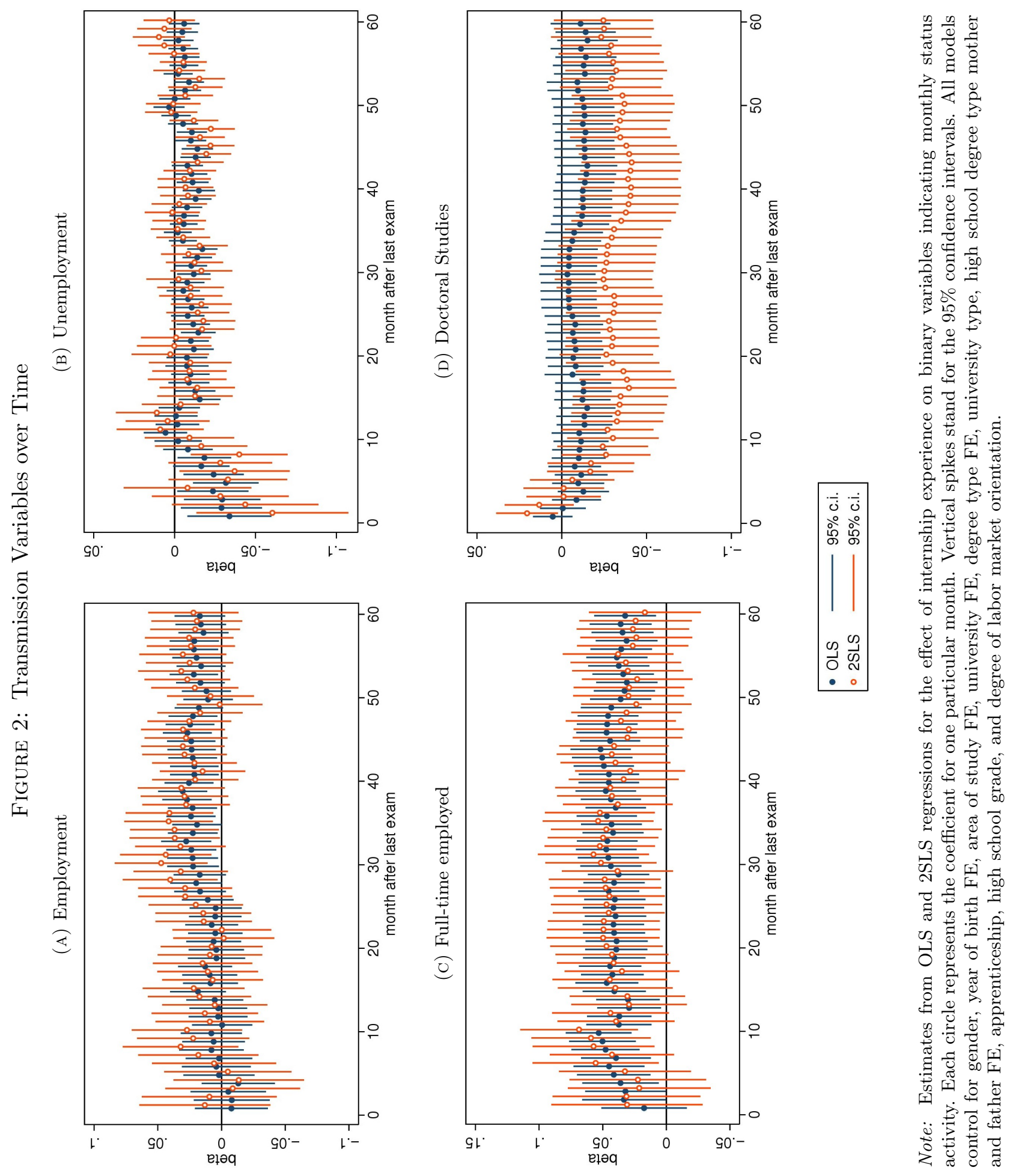


TABLE 1: Summary Statistics (Sample I)

\begin{tabular}{|c|c|c|c|c|c|}
\hline & \multirow[b]{2}{*}{ All } & \multicolumn{2}{|c|}{ Cohort } & \multicolumn{2}{|c|}{ Internship } \\
\hline & & 2001 & 2005 & No & Yes \\
\hline \multicolumn{6}{|c|}{ Panel A. Explanatory variables } \\
\hline Year of birth & 1976 & 1974 & 1978 & 1976 & 1976 \\
\hline Female & 0.54 & 0.56 & 0.52 & 0.50 & 0.56 \\
\hline Apprenticeship & 0.30 & 0.31 & 0.30 & 0.42 & 0.25 \\
\hline High school grade & 2.22 & 2.20 & 2.24 & 2.24 & 2.21 \\
\hline Labor market orientation $^{a}$ & 2.88 & 2.69 & 3.04 & 2.77 & 2.93 \\
\hline Mother has upper secondary school degree & 0.36 & 0.33 & 0.39 & 0.31 & 0.39 \\
\hline Father has upper secondary school degree & 0.49 & 0.48 & 0.51 & 0.42 & 0.53 \\
\hline University of applied sciences & 0.40 & 0.39 & 0.41 & 0.60 & 0.31 \\
\hline \multicolumn{6}{|c|}{ Panel B. Labor market variables } \\
\hline Log wages & 8.06 & 8.05 & 8.06 & 8.04 & 8.06 \\
\hline Job match: occupational status & 0.73 & 0.72 & 0.74 & 0.71 & 0.73 \\
\hline Job match: level of tasks & 0.72 & 0.72 & 0.73 & 0.71 & 0.73 \\
\hline Job match: degree & 0.66 & 0.64 & 0.68 & 0.66 & 0.66 \\
\hline Employee & 0.88 & 0.88 & 0.87 & 0.88 & 0.88 \\
\hline Civil servant & 0.02 & 0.01 & 0.03 & 0.02 & 0.02 \\
\hline Self-employed & 0.09 & 0.09 & 0.09 & 0.08 & 0.09 \\
\hline Upper management & 0.08 & 0.07 & 0.09 & 0.07 & 0.09 \\
\hline Middle management & 0.42 & 0.42 & 0.42 & 0.41 & 0.43 \\
\hline Full-time employed & 0.85 & 0.85 & 0.85 & 0.85 & 0.85 \\
\hline Permanent position & 0.70 & 0.70 & 0.70 & 0.71 & 0.69 \\
\hline Number of individuals & 6,424 & 3,042 & 3,382 & 2,146 & 4,278 \\
\hline
\end{tabular}

Note: DZHW graduate surveys 2001 and 2005. Sample $I$ according to Figure 1a. ${ }^{a}$ The variable "labor market orientation" measures how important labor market aspects were with respect to study choice, measured on a five-point scale with 5 indicating "very important" and 1 "unimportant". 
TABLE 2: Summary Statistics (Sample $I I$ )

\begin{tabular}{|c|c|c|c|c|c|c|}
\hline & \multirow[b]{2}{*}{ All } & \multicolumn{3}{|c|}{ Cohort } & \multicolumn{2}{|c|}{ Internship } \\
\hline & & 2001 & 2005 & $2009^{a}$ & No & Yes \\
\hline \multicolumn{7}{|c|}{ Panel A. Explanatory variables } \\
\hline Year of birth & 1977 & 1974 & 1978 & 1982 & 1976 & 1977 \\
\hline Female & 0.53 & 0.55 & 0.52 & 0.53 & 0.48 & 0.55 \\
\hline Apprenticeship & 0.30 & 0.31 & 0.31 & 0.26 & 0.42 & 0.24 \\
\hline High school grade & 2.23 & 2.21 & 2.25 & 2.24 & 2.26 & 2.22 \\
\hline Labor market orientation $^{b}$ & 2.91 & 2.71 & 3.07 & 2.92 & 2.81 & 2.96 \\
\hline Mother has upper secondary school degree & 0.37 & 0.34 & 0.39 & 0.42 & 0.32 & 0.40 \\
\hline Father has upper secondary school degree & 0.50 & 0.49 & 0.51 & 0.52 & 0.44 & 0.54 \\
\hline University of applied sciences & 0.41 & 0.40 & 0.43 & 0.35 & 0.59 & 0.31 \\
\hline \multicolumn{7}{|c|}{ Panel B. Labor market variables } \\
\hline Log wages & 7.72 & 7.83 & 7.69 & 7.48 & 7.72 & 7.71 \\
\hline Job match: occupational status & 0.19 & 0.16 & 0.20 & 0.17 & 0.18 & 0.19 \\
\hline Job match: level of tasks & 0.18 & 0.15 & 0.19 & 0.17 & 0.17 & 0.18 \\
\hline Job match: degree & 0.20 & 0.19 & 0.20 & 0.18 & 0.19 & 0.20 \\
\hline Employee & 0.84 & 0.91 & 0.79 & 0.85 & 0.85 & 0.84 \\
\hline Civil servant & 0.03 & 0.01 & 0.04 & 0.05 & 0.02 & 0.03 \\
\hline Self-employed & 0.09 & 0.06 & 0.11 & 0.08 & 0.08 & 0.09 \\
\hline Upper management & 0.04 & 0.04 & 0.04 & 0.03 & 0.04 & 0.03 \\
\hline Middle management & 0.34 & 0.33 & 0.34 & 0.33 & 0.35 & 0.33 \\
\hline Full-time employed & 0.74 & 0.77 & 0.72 & 0.67 & 0.72 & 0.74 \\
\hline Permanent position & 0.55 & 0.63 & 0.50 & 0.46 & 0.56 & 0.54 \\
\hline Number of individuals & 13,630 & 4,874 & 6,117 & 2,639 & 4,618 & 9,012 \\
\hline Number of observations & 19,218 & 7,590 & 8,989 & 2,639 & 6,486 & 12,732 \\
\hline
\end{tabular}

Note: DZHW graduate surveys 2001, 2005 and 2009. Sample II according to Figure 1b. ${ }^{a}$ Data only from the first wave. ${ }^{b}$ The variable "labor market orientation" measures how important labor market aspects were with respect to study choice, measured on a five-point scale with 5 indicating "very important" and 1 "unimportant". 


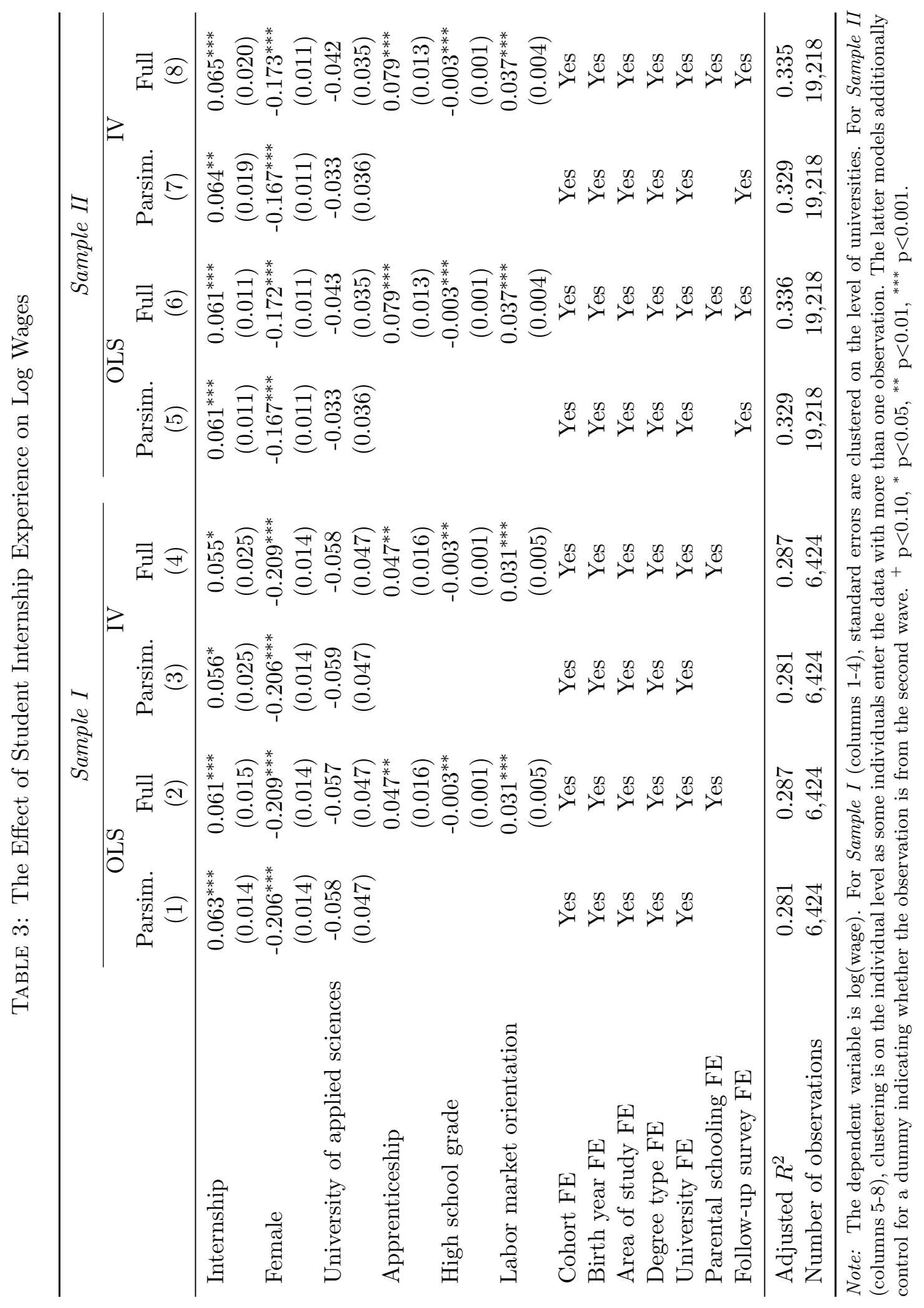


TABLE 4: First-Stage Results

\begin{tabular}{|c|c|c|c|c|}
\hline & \multicolumn{2}{|c|}{ Sample I } & \multicolumn{2}{|c|}{ Sample II } \\
\hline & $\begin{array}{c}\text { Parsim. } \\
\text { (1) }\end{array}$ & $\begin{array}{c}\text { Full } \\
(2)\end{array}$ & $\begin{array}{c}\text { Parsim. } \\
(3)\end{array}$ & $\begin{array}{c}\text { Full } \\
(4)\end{array}$ \\
\hline Mandatory internship & $\begin{array}{c}0.581^{* * *} \\
(0.015)\end{array}$ & $\begin{array}{c}0.574^{* * *} \\
(0.015)\end{array}$ & $\begin{array}{c}0.567^{* * *} \\
(0.008)\end{array}$ & $\begin{array}{c}0.560^{* * *} \\
(0.008)\end{array}$ \\
\hline Female & $\begin{array}{c}0.016 \\
(0.012)\end{array}$ & $\begin{array}{l}0.022^{+} \\
(0.012)\end{array}$ & $\begin{array}{l}0.020^{* *} \\
(0.008)\end{array}$ & $\begin{array}{l}0.025^{* *} \\
(0.008)\end{array}$ \\
\hline University of applied sciences & $\begin{array}{c}-0.133^{* *} \\
(0.045)\end{array}$ & $\begin{array}{c}-0.119^{* *} \\
(0.043)\end{array}$ & $\begin{array}{c}-0.089^{* *} \\
(0.028)\end{array}$ & $\begin{array}{c}-0.077^{* *} \\
(0.027)\end{array}$ \\
\hline Apprenticeship & & $\begin{array}{c}-0.080^{* * *} \\
(0.016)\end{array}$ & & $\begin{array}{c}-0.084^{* * *} \\
(0.010)\end{array}$ \\
\hline High school grade & & $\begin{array}{l}-0.001 \\
(0.001)\end{array}$ & & $\begin{array}{l}-0.001 \\
(0.001)\end{array}$ \\
\hline Labor market orientation & & $\begin{array}{c}0.020^{* * *} \\
(0.004)\end{array}$ & & $\begin{array}{c}0.019^{* * *} \\
(0.003)\end{array}$ \\
\hline Cohort FE & Yes & Yes & Yes & Yes \\
\hline Birth year FE & Yes & Yes & Yes & Yes \\
\hline Area of study FE & Yes & Yes & Yes & Yes \\
\hline Degree type FE & Yes & Yes & Yes & Yes \\
\hline University FE & Yes & Yes & Yes & Yes \\
\hline Parental schooling FE & & Yes & & Yes \\
\hline Follow-up survey FE & & & Yes & Yes \\
\hline Adjusted $R^{2}$ & 0.465 & 0.471 & 0.461 & 0.467 \\
\hline F-statistic & 38.244 & 37.806 & 70.412 & 69.420 \\
\hline Number of observations & 6,424 & 6,424 & 19,218 & 19,218 \\
\hline
\end{tabular}

Note: The dependent variable is equal to one if a graduate completed an internship during the course of studies, and zero otherwise. Standard errors in parentheses. ${ }^{+} \mathrm{p}<0.10$, ${ }^{*} \mathrm{p}<0.05,{ }^{* *} \mathrm{p}<0.01,{ }^{* * *} \mathrm{p}<0.001$. 


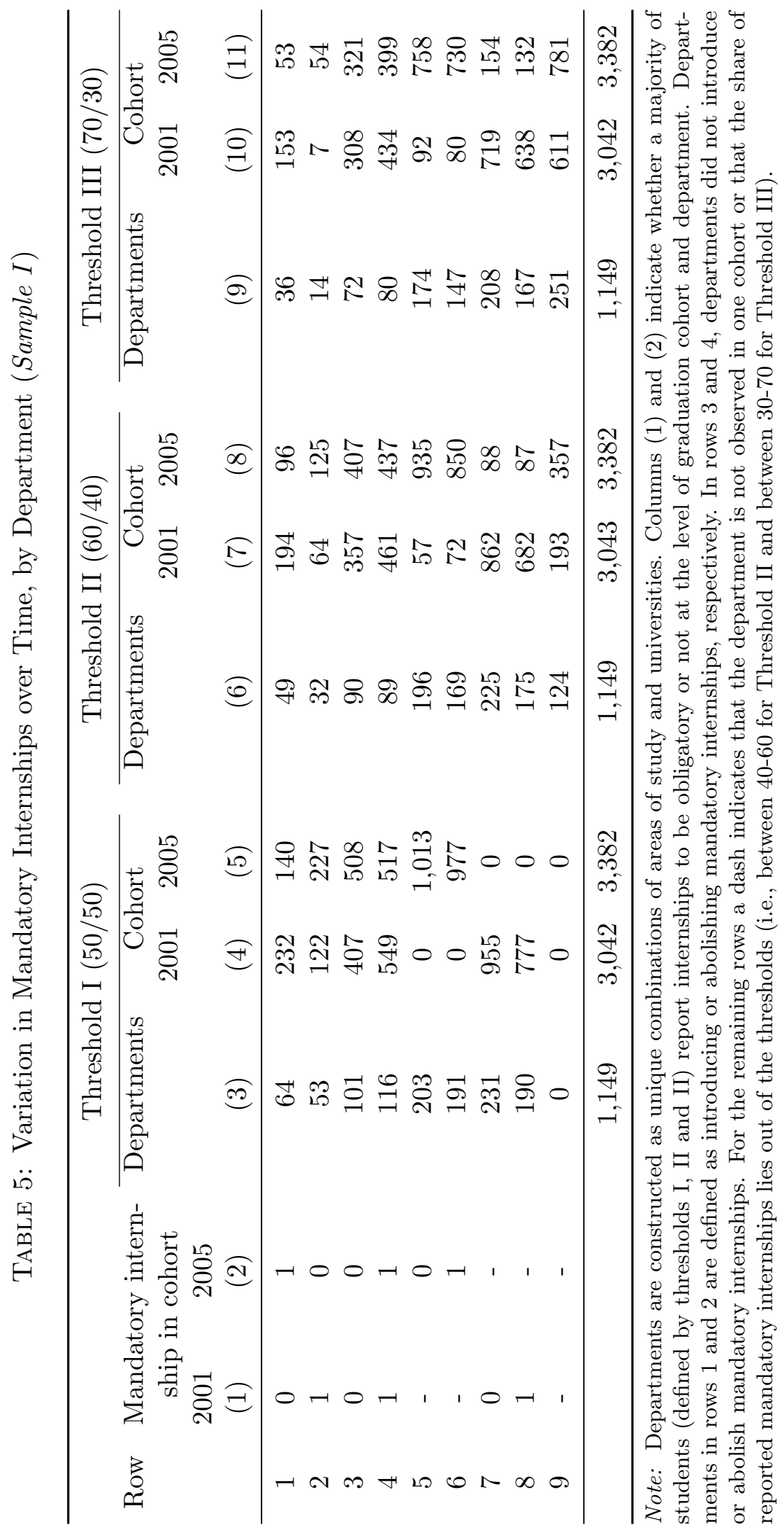


TABle 6: DiD Estimates of Introducing Mandatory Internships on Quality Indicators (Sample $I$ )

\begin{tabular}{|c|c|c|c|c|}
\hline Comparison group: & \multicolumn{2}{|c|}{$\begin{array}{c}\text { Departments } \\
\text { without a change } \\
\text { in mandatory internship }\end{array}$} & \multicolumn{2}{|c|}{$\begin{array}{l}\text { Departments } \\
\text { without a manda- } \\
\text { tory internship }\end{array}$} \\
\hline Controls: & No & Yes & No & Yes \\
\hline & (1) & $(2)$ & $(3)$ & (4) \\
\hline
\end{tabular}

Overall quality of education:

Structure of the study program

$\begin{array}{lccc}-0.059 & 0.001 & -0.086 & 0.002 \\ (0.111) & (0.130) & (0.120) & (0.149) \\ -0.044 & 0.174 & -0.033 & 0.220 \\ (0.108) & (0.135) & (0.116) & (0.158) \\ -0.067 & 0.030 & -0.146 & -0.007 \\ (0.123) & (0.149) & (0.133) & (0.172)\end{array}$

Educational media and infrastructure:

Availability of literature in the library

$\begin{array}{lccc}-0.001 & 0.093 & -0.081 & 0.062 \\ (0.129) & (0.155) & (0.144) & (0.186)\end{array}$

Access to IT services (internet, databases)

$-0.032$

0.046

0.023

0.198

Laboratory facilities

$(0.112)$

$(0.136)$

(0.122)

(0.161)

$-0.640^{\mathrm{c}}$

$0.051^{\mathrm{c}}$

$0.024^{\mathrm{d}}$

$0.234^{\mathrm{d}}$

(0.137)

(0.169)

(0.151)

(0.203)

Training:

Oral presentation training

$\begin{array}{cccc}-0.134 & -0.016 & -0.124 & 0.101 \\ (0.146) & (0.180) & (0.154) & (0.210) \\ -0.238^{+} & -0.323^{+} & -0.288^{+} & -0.398^{+} \\ (0.141) & (0.174) & (0.152) & (0.203) \\ -0.055 & 0.038 & 0.024 & 0.192 \\ (0.141) & (0.166) & (0.153) & (0.200)\end{array}$

Career Counseling:

Writing skills training

Training in foreign languages ${ }^{\mathrm{b}}$

(0.141)

$(0.166)$

$(0.153)$

$(0.200)$

Help in finding a job and starting a career

0.050

0.081

$-0.022$

0.114

(0.136)

(0.167)

$(0.146)$

(0.194)

Availability of career counseling

0.036

0.188

$-0.035$

0.177

Provision of career orientation events

(0.126)

$(0.155)$

$(0.137)$

(0.179)

0.063

0.067

$-0.026$

0.011

(0.125)

(0.155)

(0.133)

(0.180)

\begin{tabular}{lllll}
\hline Number of observations & 2,159 & 2,159 & 1,171 & 1,171 \\
\hline
\end{tabular}

Note: Estimates from DiD regressions, based on threshold I (50/50) definition of treatment. Standard errors in parentheses. No control variables in columns (1) and (3). In columns (2) and (4), the set of control variables comprises gender, year of birth FE, area of study FE, university FE, degree type FE, university type, high school degree type mother and father FE, apprenticeship, high school grade, and degree of labor market orientation. The models in columns (1) and (2) comprise all individuals from rows 1, 3 and 4 of Table 5, for whom the outcome variable is not missing. The models in columns (3) and (4) comprise individuals only from rows 1 and $3{ }^{a}$ The variable measures the actuality of education with respect to current job requirements. ${ }^{b}$ The variable measures subject- or job-specific training in foreign languages. ${ }^{c}$ Sample size $N=1,723 .{ }^{d}$ Sample size $N=1,108 .{ }^{+} \mathrm{p}<0.10,{ }^{*} \mathrm{p}<0.05,{ }^{* *} \mathrm{p}<0.01,{ }^{* * *} \mathrm{p}<0.001$. 
TABLE 7: DiD Estimates of Abolishing Mandatory Internships on Quality Indicators (Sample I)

\begin{tabular}{|c|c|c|c|c|}
\hline \multirow{3}{*}{$\begin{array}{l}\text { Comparison group: } \\
\text { Controls: }\end{array}$} & \multicolumn{2}{|c|}{$\begin{array}{l}\text { Departments } \\
\text { without a change in } \\
\text { mandatory internship }\end{array}$} & \multicolumn{2}{|c|}{$\begin{array}{l}\text { Departments } \\
\text { with a manda- } \\
\text { tory internship }\end{array}$} \\
\hline & No & Yes & No & Yes \\
\hline & (1) & $(2)$ & $(3)$ & $(4)$ \\
\hline \multicolumn{5}{|l|}{ Overall quality of education: } \\
\hline Structure of the study program & $\begin{array}{l}-0.055 \\
(0.111)\end{array}$ & $\begin{array}{c}0.139 \\
(0.121)\end{array}$ & $\begin{array}{l}-0.017 \\
(0.116)\end{array}$ & $\begin{array}{c}0.127 \\
(0.133)\end{array}$ \\
\hline State-of-the-art methods taught & $\begin{array}{l}-0.011 \\
(0.110)\end{array}$ & $\begin{array}{c}-0.164 \\
(0.126)\end{array}$ & $\begin{array}{l}-0.014 \\
(0.117)\end{array}$ & $\begin{array}{l}-0.193 \\
(0.139)\end{array}$ \\
\hline Up-to-date education ${ }^{\mathrm{a}}$ & $\begin{array}{r}-0.232^{+} \\
(0.125)\end{array}$ & $\begin{array}{c}-0.181 \\
(0.139)\end{array}$ & $\begin{array}{l}-0.148 \\
(0.132)\end{array}$ & $\begin{array}{l}-0.179 \\
(0.158)\end{array}$ \\
\hline \multicolumn{5}{|l|}{ Educational media and infrastructure: } \\
\hline Availability of literature in the library & $\begin{array}{l}-0.072 \\
(0.129)\end{array}$ & $\begin{array}{l}-0.043 \\
(0.144)\end{array}$ & $\begin{array}{l}-0.021 \\
(0.133)\end{array}$ & $\begin{array}{c}0.037 \\
(0.155)\end{array}$ \\
\hline Access to IT services (internet, databases) & $\begin{array}{c}0.054 \\
(0.112)\end{array}$ & $\begin{array}{c}0.189 \\
(0.124)\end{array}$ & $\begin{array}{c}0.018 \\
(0.120)\end{array}$ & $\begin{array}{c}0.056 \\
(0.136)\end{array}$ \\
\hline Laboratory facilities & $\begin{array}{l}-0.034^{\mathrm{c}} \\
(0.130)\end{array}$ & $\begin{array}{l}-0.030^{\mathrm{c}} \\
(0.140)\end{array}$ & $\begin{array}{c}-0.070^{\mathrm{d}} \\
(0.134)\end{array}$ & $\begin{array}{c}-0.142^{\mathrm{d}} \\
(0.151)\end{array}$ \\
\hline \multicolumn{5}{|l|}{ Training: } \\
\hline Oral presentation training & $\begin{array}{c}0.007 \\
(0.149)\end{array}$ & $\begin{array}{c}0.111 \\
(0.169)\end{array}$ & $\begin{array}{c}0.018 \\
(0.159)\end{array}$ & $\begin{array}{c}0.005 \\
(0.187)\end{array}$ \\
\hline Writing skills training & $\begin{array}{l}-0.160 \\
(0.142)\end{array}$ & $\begin{array}{l}-0.261 \\
(0.162)\end{array}$ & $\begin{array}{l}-0.119 \\
(0.149)\end{array}$ & $\begin{array}{l}-0.172 \\
(0.178)\end{array}$ \\
\hline Training in foreign languages ${ }^{b}$ & $\begin{array}{c}0.087 \\
(0.145)\end{array}$ & $\begin{array}{c}0.133 \\
(0.156)\end{array}$ & $\begin{array}{c}0.045 \\
(0.150)\end{array}$ & $\begin{array}{c}0.070 \\
(0.168)\end{array}$ \\
\hline \multicolumn{5}{|l|}{ Career Counseling: } \\
\hline Help in finding a job and starting a career & $\begin{array}{l}-0.151 \\
(0.140)\end{array}$ & $\begin{array}{l}-0.055 \\
(0.159)\end{array}$ & $\begin{array}{l}-0.080 \\
(0.148)\end{array}$ & $\begin{array}{l}-0.006 \\
(0.178)\end{array}$ \\
\hline Availability of career counseling & $\begin{array}{l}-0.200 \\
(0.129)\end{array}$ & $\begin{array}{c}0.012 \\
(0.147)\end{array}$ & $\begin{array}{l}-0.129 \\
(0.135)\end{array}$ & $\begin{array}{c}0.036 \\
(0.163)\end{array}$ \\
\hline Provision of career orientation events & $\begin{array}{c}0.007 \\
(0.126)\end{array}$ & $\begin{array}{c}0.146 \\
(0.145)\end{array}$ & $\begin{array}{c}0.089 \\
(0.133)\end{array}$ & $\begin{array}{l}0.269^{+} \\
(0.161)\end{array}$ \\
\hline Number of observations & 2,155 & 2,155 & 1,314 & 1,314 \\
\hline
\end{tabular}

Note: Estimates from DiD regressions, based on threshold I (50/50) definition of treatment. Standard errors in parentheses. No control variables in columns (1) and (3). In columns (2) and (4), the set of control variables comprises gender, year of birth FE, area of study FE, university FE, degree type FE, university type, high school degree type mother and father FE, apprenticeship, high school grade, and degree of labor market orientation. The models in columns (1) and (2) comprise all individuals from rows 2,3 and 4 of Table 5, for whom the outcome variable is not missing. The models in columns (3) and (4) comprise individuals only from rows 2 and $4 .{ }^{a}$ The variable measures the actuality of education with respect to current job requirements. ${ }^{b}$ The variable measures subject- or job-specific training in foreign languages. ${ }^{c}$ Sample size $N=1,723 .{ }^{d}$ Sample size $N=1,108 .{ }^{+} \mathrm{p}<0.10,{ }^{*} \mathrm{p}<0.05,{ }^{* *} \mathrm{p}<0.01,{ }^{* * *} \mathrm{p}<0.001$. 
TABLE 8: DiD Estimates of Introducing/Abolishing Mandatory Internships on Individual Characteristics (Threshold I: 50/50, Sample I)

\begin{tabular}{|c|c|c|c|c|}
\hline Comparison group: & \multicolumn{2}{|c|}{$\begin{array}{l}\text { Departments } \\
\text { without a change in } \\
\text { mandatory internship }\end{array}$} & \multicolumn{2}{|c|}{$\begin{array}{c}\text { Departments } \\
\text { with/without a } \\
\text { mandatory internship }\end{array}$} \\
\hline Controls: & No & Yes & No & Yes \\
\hline & (1) & $(2)$ & (3) & $(4)$ \\
\hline
\end{tabular}

Panel A. Treatment: Introduction of a Mandatory Internship

$\begin{array}{lcccc}\text { Mother has an upper sec. high school degree } & 0.002 & -0.002 & -0.020 & -0.020 \\ & (0.056) & (0.069) & (0.060) & (0.081) \\ \text { Father has an upper sec. high school degree } & 0.019 & 0.079 & 0.027 & 0.086 \\ & (0.058) & (0.072) & (0.063) & (0.085) \\ \text { Labor market orientation } & 0.077 & -0.044 & 0.037 & -0.097 \\ & (0.141) & (0.177) & (0.154) & (0.210) \\ \text { High school grade } & 0.199 & -0.559 & -0.122 & -1.428 \\ & (0.713) & (0.798) & (0.779) & (0.946) \\ \text { Number of observations } & 2,353 & 2,353 & 1,287 & 1,287\end{array}$

Panel B. Treatment: Abolishment of a Mandatory Internship

$\begin{array}{lcccc}\text { Mother has an upper sec. high school degree } & 0.031 & 0.047 & 0.041 & 0.106 \\ & (0.058) & (0.067) & (0.062) & (0.074) \\ \text { Father has an upper sec. high school degree } & -0.063 & -0.040 & -0.078 & -0.024 \\ & (0.060) & (0.069) & (0.064) & (0.077) \\ \text { Labor market orientation } & 0.000 & 0.008 & 0.032 & 0.052 \\ & (0.147) & (0.171) & (0.155) & (0.189) \\ \text { High school grade } & 0.868 & 0.087 & 1.053 & -0.022 \\ & (0.738) & (0.774) & (0.781) & (0.857) \\ \text { Number of observations } & 2,330 & 2,330 & 1,415 & 1,415\end{array}$

Note: Estimates from DiD regressions, based on threshold I (50/50) definition of treatment. Standard errors in parentheses. No control variables in columns (1) and (3). In columns (2) and (4), the set of control variables comprises gender, year of birth FE, area of study FE, university FE, degree type FE, university type, high school degree type mother and father FE, apprenticeship, high school grade, and degree of labor market orientation. Each row's dependent variable is omitted from the set of controls variables. Panel A: The models in columns (1) and (2) comprise all individuals from rows 1, 3 and 4 of Table 5, for whom the outcome variable is not missing. The models in columns (3) and (4) comprise individuals only from rows 1 and 3. Panel B: The models in columns (1) and (2) comprise all individuals from rows 2, 3 and 4 of Table 5, for whom the outcome variable is not missing. The models in columns (3) and (4) comprise individuals only from rows 2 and 4 . For alternative threshold definitions, see Tables A.1 and A.2. ${ }^{+} \mathrm{p}<0.10,{ }^{*} \mathrm{p}<0.05,{ }^{* *} \mathrm{p}<0.01,{ }^{* * *} \mathrm{p}<0.001$. 
TABLE 9: Heterogeneous Effects

\begin{tabular}{|c|c|c|c|c|c|c|}
\hline & \multicolumn{3}{|c|}{ Sample I } & \multicolumn{3}{|c|}{ Sample II } \\
\hline & $\begin{array}{l}\text { OLS } \\
(1)\end{array}$ & $\begin{array}{l}\text { IV } \\
(2)\end{array}$ & $\begin{array}{l}\text { Obs. } \\
(3)\end{array}$ & $\begin{array}{l}\text { OLS } \\
(4)\end{array}$ & $\begin{array}{l}\text { IV } \\
(5)\end{array}$ & $\begin{array}{c}\text { Obs. } \\
(6)\end{array}$ \\
\hline \multicolumn{7}{|l|}{ Panel A: Gender } \\
\hline Women & $\begin{array}{c}0.077^{* *} \\
(0.028)\end{array}$ & $\begin{array}{c}0.083^{+} \\
(0.043)\end{array}$ & 3,448 & $\begin{array}{c}0.075^{\text {*** }} \\
(0.017)\end{array}$ & $\begin{array}{l}0.060^{+} \\
(0.032)\end{array}$ & 10,177 \\
\hline Men & $\begin{array}{l}0.043^{* *} \\
(0.016)\end{array}$ & $\begin{array}{c}0.042 \\
(0.028)\end{array}$ & 2,976 & $\begin{array}{c}0.053^{* * *} \\
(0.025)\end{array}$ & $\begin{array}{l}0.079^{* *} \\
(0.025)\end{array}$ & 9,041 \\
\hline $\mathrm{P}$-value of interaction & 0.312 & 0.513 & 6,424 & 0.229 & 0.885 & 19,218 \\
\hline \multicolumn{7}{|l|}{ Panel B: Parental background } \\
\hline Parents with 'low' levels of schooling & $\begin{array}{l}0.052^{*} \\
(0.021)\end{array}$ & $\begin{array}{c}0.038 \\
(0.036)\end{array}$ & 2,840 & $\begin{array}{l}0.047^{* *} \\
(0.016)\end{array}$ & $\begin{array}{c}0.044 \\
(0.028)\end{array}$ & 8,241 \\
\hline Parents with 'high' levels of schooling & $\begin{array}{c}0.052^{*} \\
(0.022)\end{array}$ & $\begin{array}{c}0.040 \\
(0.035)\end{array}$ & 3,584 & $\begin{array}{c}0.065^{* * *} \\
(0.016)\end{array}$ & $\begin{array}{l}0.069^{*} \\
(0.029)\end{array}$ & 10,977 \\
\hline P-value of interaction & 0.382 & 0.352 & 6,424 & 0.365 & 0.528 & 19,218 \\
\hline \multicolumn{7}{|l|}{ Panel C: High school performance } \\
\hline High school grade $<$ median & $\begin{array}{c}0.050^{*} \\
(0.022)\end{array}$ & $\begin{array}{c}0.066 \\
(0.041)\end{array}$ & 3,246 & $\begin{array}{c}0.069^{* * *} \\
(0.017)\end{array}$ & $\begin{array}{c}0.101^{* *} \\
(0.031)\end{array}$ & 9,634 \\
\hline High school grade $\geq$ median & $\begin{array}{l}0.066^{* *} \\
(0.020)\end{array}$ & $\begin{array}{l}0.070^{+} \\
(0.036)\end{array}$ & 3,178 & $\begin{array}{l}0.049^{* *} \\
(0.015)\end{array}$ & $\begin{array}{c}0.034 \\
(0.027)\end{array}$ & 9,854 \\
\hline P-value of interaction & 0.579 & 0.898 & 6,424 & 0.400 & 0.274 & 19,218 \\
\hline \multicolumn{7}{|c|}{ Panel D: Labor market orientation of student } \\
\hline LM orientation $<$ median & $\begin{array}{c}0.072^{* *} \\
(0.022)\end{array}$ & $\begin{array}{c}0.062^{*} \\
(0.031)\end{array}$ & 3,364 & $\begin{array}{c}0.072^{* * *} \\
(0.016)\end{array}$ & $\begin{array}{c}0.098^{* * *} \\
(0.028)\end{array}$ & 9,818 \\
\hline LM orientation $\geq$ median & $\begin{array}{c}0.043^{*} \\
(0.019)\end{array}$ & $\begin{array}{c}0.034 \\
(0.041)\end{array}$ & 3,060 & $\begin{array}{l}0.041^{* *} \\
(0.016)\end{array}$ & $\begin{array}{c}0.008 \\
(0.029)\end{array}$ & 9,400 \\
\hline P-value of interaction & 0.452 & 0.536 & 6,424 & 0.581 & 0.066 & 19,218 \\
\hline \multicolumn{7}{|c|}{ Panel E: Labor market orientation of study subject ${ }^{a}$} \\
\hline Strong LM orientation & $\begin{array}{c}0.053^{* * *} \\
(0.015)\end{array}$ & $\begin{array}{l}0.051^{+} \\
(0.026)\end{array}$ & 4,815 & $\begin{array}{c}0.049^{* * *} \\
(0.011)\end{array}$ & $\begin{array}{c}0.050^{* *} \\
(0.019)\end{array}$ & 14,440 \\
\hline Weak LM orientation & $\begin{array}{c}0.066 \\
(0.053)\end{array}$ & $\begin{array}{l}0.165^{+} \\
(0.087)\end{array}$ & 1,609 & $\begin{array}{l}0.104^{* *} \\
(0.035)\end{array}$ & $\begin{array}{l}0.132^{+} \\
(0.076)\end{array}$ & 4,778 \\
\hline $\mathrm{P}$-value of interaction & 0.679 & 0.499 & 6,424 & 0.097 & 0.076 & 19,218 \\
\hline
\end{tabular}

Note: ${ }^{a}$ See Table A.3 in the appendix for a classification of areas of studies into weak and strong labor market orientation. All models control for gender, year of birth FE, area of study FE, university FE, degree type FE, university type, high school degree type mother and father FE, apprenticeship, high school grade, and degree of labor market orientation. $+\mathrm{p}<0.10,{ }^{*} \mathrm{p}<0.05,{ }^{* *} \mathrm{p}<0.01,{ }^{* * *} \mathrm{p}<0.001$. 
TABLE 10: The Effect of Internship Experience on Intermediary Variables (Sample I)

\begin{tabular}{|c|c|c|c|}
\hline & OLS & IV & $\begin{array}{l}\text { Number of } \\
\text { observations }\end{array}$ \\
\hline \multicolumn{4}{|l|}{ Panel A: Matching } \\
\hline Job match: occupational status & $\begin{array}{l}0.030^{*} \\
(0.012)\end{array}$ & $\begin{array}{l}-0.004 \\
(0.024)\end{array}$ & 6,404 \\
\hline Job match: level of tasks & $\begin{array}{l}0.035^{* *} \\
(0.012)\end{array}$ & $\begin{array}{c}0.013 \\
(0.025)\end{array}$ & 6,394 \\
\hline Job match: degree & $\begin{array}{c}0.016 \\
(0.016)\end{array}$ & $\begin{array}{c}-0.021 \\
(0.025)\end{array}$ & 6,389 \\
\hline \multicolumn{4}{|l|}{ Panel B: Employment } \\
\hline Full-time employed & $\begin{array}{l}0.027^{*} \\
(0.011)\end{array}$ & $\begin{array}{l}0.037^{+} \\
(0.019)\end{array}$ & 6,040 \\
\hline Permanent position & $\begin{array}{l}-0.012 \\
(0.014)\end{array}$ & $\begin{array}{l}-0.037 \\
(0.025)\end{array}$ & 6,424 \\
\hline \multicolumn{4}{|l|}{ Panel C: Occupation } \\
\hline Employee & $\begin{array}{c}0.005 \\
(0.009)\end{array}$ & $\begin{array}{c}0.020 \\
(0.017)\end{array}$ & 6,424 \\
\hline Civil servant & $\begin{array}{l}-0.004 \\
(0.005)\end{array}$ & $\begin{array}{l}-0.002 \\
(0.009)\end{array}$ & 6,424 \\
\hline Self-employed & $\begin{array}{c}0.007 \\
(0.008)\end{array}$ & $\begin{array}{l}-0.001 \\
(0.016)\end{array}$ & 6,424 \\
\hline \multicolumn{4}{|l|}{ Panel D: Job position } \\
\hline Upper management & $\begin{array}{c}0.004 \\
(0.008)\end{array}$ & $\begin{array}{c}0.015 \\
(0.016)\end{array}$ & 6,424 \\
\hline Medium management & $\begin{array}{c}0.015 \\
(0.015)\end{array}$ & $\begin{array}{c}0.005 \\
(0.028)\end{array}$ & 6,424 \\
\hline \multicolumn{4}{|l|}{ Panel E: Doctoral studies } \\
\hline Currently PhD student & $\begin{array}{l}-0.013 \\
(0.009)\end{array}$ & $\begin{array}{l}-0.010 \\
(0.012)\end{array}$ & 6,423 \\
\hline Ever started $\mathrm{PhD}$ & $\begin{array}{l}-0.012 \\
(0.010)\end{array}$ & $\begin{array}{l}-0.037^{*} \\
(0.015)\end{array}$ & 6,406 \\
\hline Ever completed PhD & $\begin{array}{c}0.001 \\
(0.009)\end{array}$ & $\begin{array}{c}-0.033^{* *} \\
(0.012)\end{array}$ & 6,406 \\
\hline
\end{tabular}

Note: All models control for gender, year of birth FE, area of study FE, university FE, degree type FE, university type, high school degree type mother and father FE, apprenticeship, high school grade, and degree of labor market orientation. $+\mathrm{p}<0.10,{ }^{*} \mathrm{p}<0.05,{ }^{* *} \mathrm{p}<0.01,{ }^{* * *} \mathrm{p}<0.001$. 
TABLE 11: Wage regressions: The Impact of Intermediary Variables

\begin{tabular}{lcc}
\hline & $\begin{array}{c}\text { Over-specified } \\
\text { OLS }\end{array}$ & $\begin{array}{c}\text { Over-specified } \\
\text { IV }\end{array}$ \\
\hline Internship & $0.036^{* *}$ & 0.022 \\
& $(0.012)$ & $(0.021)$ \\
Full-time employed & $0.503^{* * *}$ & $0.503^{* * *}$ \\
& $(0.023)$ & $(0.023)$ \\
Ever started PhD & $-0.069^{* * *}$ & $-0.069^{* * *}$ \\
Completed PhD & $(0.017)$ & $(0.017)$ \\
& $0.062^{* *}$ & $0.062^{* *}$ \\
Number of months employed & $(0.023)$ & $(0.023)$ \\
& $0.008^{* * *}$ & $0.008^{* * *}$ \\
Number of months unemployed & $(0.001)$ & $(0.001)$ \\
& $-0.008^{* * *}$ & $-0.008^{* * *}$ \\
& $(0.002)$ & $(0.002)$ \\
\hline Adjusted $R^{2}$ & 0.491 & 0.491 \\
Number of observations & 6,424 & 6,424 \\
\hline
\end{tabular}

Note: The dependent variable is $\log$ (wage). The variable months (un)employed can take values from zero to 60 . Unreported explanatory variables include gender, year of birth FE, area of study FE, university FE, degree type FE, university type, high school degree type mother and father FE, apprenticeship, high school grade, and degree of labor market orientation. ${ }^{+} \mathrm{p}<0.10,{ }^{*} \mathrm{p}<0.05,{ }^{* *} \mathrm{p}<0.01$, *** $\mathrm{p}<0.001$. 
TABle 12: Robustness Checks I : Alternative Instruments

\begin{tabular}{|c|c|c|c|c|c|}
\hline & $\begin{array}{l}I V_{50} \\
(1)\end{array}$ & $\begin{array}{c}I V_{60} \\
(2)\end{array}$ & $\begin{array}{c}I V_{70} \\
(3)\end{array}$ & $\begin{array}{c}I V_{\text {Ratio }_{1}} \\
\quad(4)\end{array}$ & $\begin{array}{c}I V_{\text {Ratio }_{2}} \\
(5)\end{array}$ \\
\hline \multicolumn{6}{|c|}{ Panel A: Sample I } \\
\hline Internship & $\begin{array}{l}0.112^{+} \\
(0.067)\end{array}$ & $\begin{array}{c}0.088 \\
(0.072)\end{array}$ & $\begin{array}{c}0.057 \\
(0.069)\end{array}$ & $\begin{array}{c}0.088 \\
(0.065)\end{array}$ & $\begin{array}{c}0.088^{*} \\
(0.043)\end{array}$ \\
\hline First-stage estimate & $\begin{array}{c}0.293^{* * *} \\
(0.02)\end{array}$ & $\begin{array}{c}0.354^{* * *} \\
(0.022)\end{array}$ & $\begin{array}{c}0.413^{* * *} \\
(0.027)\end{array}$ & $\begin{array}{c}0.500^{* * *} \\
(0.027)\end{array}$ & $\begin{array}{c}0.521^{* * *} \\
(0.022)\end{array}$ \\
\hline F-statistic & 14.65 & 16.37 & 15.41 & 18.36 & 23.56 \\
\hline Number of observations & 6,424 & 5,470 & 4,574 & 6,424 & 6,424 \\
\hline \multicolumn{6}{|c|}{ Panel B: Sample II } \\
\hline Internship & $\begin{array}{c}0.085 \\
(0.061)\end{array}$ & $\begin{array}{c}0.121^{*} \\
(0.051)\end{array}$ & $\begin{array}{c}0.151^{* *} \\
(0.055)\end{array}$ & $\begin{array}{c}0.113^{*} \\
(0.044)\end{array}$ & $\begin{array}{c}0.125^{* * *} \\
(0.033)\end{array}$ \\
\hline First-stage estimate & $\begin{array}{c}0.270^{* * *} \\
(0.012)\end{array}$ & $\begin{array}{c}0.341^{* * *} \\
(0.014)\end{array}$ & $\begin{array}{c}0.392^{* * *} \\
(0.017)\end{array}$ & $\begin{array}{c}0.477^{* * *} \\
(0.016)\end{array}$ & $\begin{array}{c}0.509^{* * *} \\
(0.012)\end{array}$ \\
\hline F-statistic & 22.44 & 24.61 & 23.66 & 29.57 & 40.76 \\
\hline Number of observations & 19,218 & 16,360 & 13,609 & 19,218 & 19,218 \\
\hline
\end{tabular}

Note: All models control for gender, year of birth FE, area of study FE, university FE, degree type FE, university type, high school degree type mother and father FE, apprenticeship, high school grade, and degree of labor market orientation. ${ }^{+} \mathrm{p}<0.10,{ }^{*} \mathrm{p}<0.05,{ }^{* *} \mathrm{p}<0.01$, *** $\mathrm{p}<0.001$. 
TABle 13: Robustness Checks II: Specification and Sample Selection

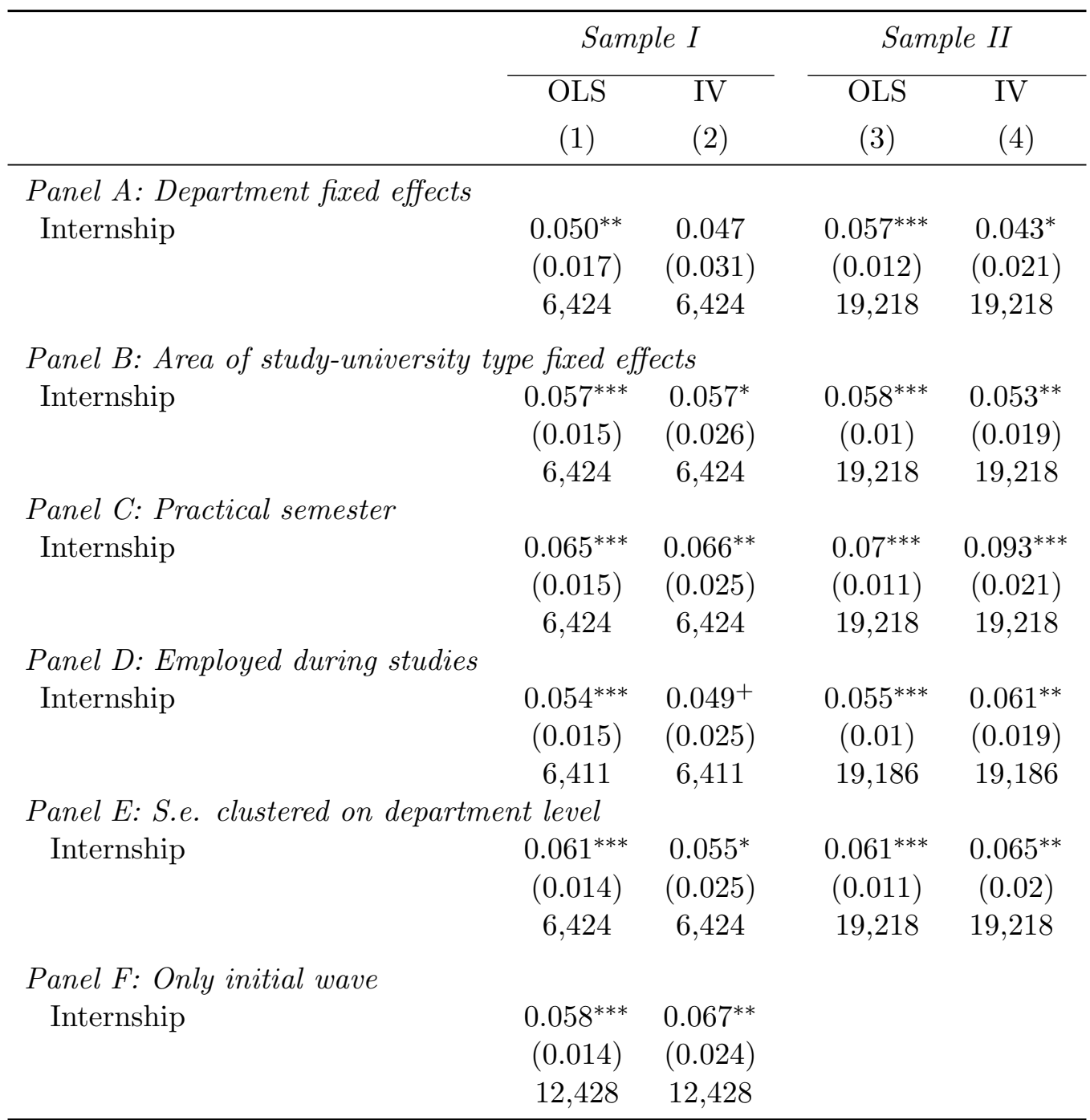

Note: All models control for gender, year of birth FE, area of study FE, university FE, degree type FE, university type, high school degree type mother and father FE, apprenticeship, high school grade, and degree of labor market orientation. Exceptions: The regression in panel A omits area of study and university FE due to the newly introduced department FE. Panel $\mathrm{B}$ omits area of study FE and the dummy indicating the university type. ${ }^{+} \mathrm{p}<0.10,{ }^{*} \mathrm{p}<0.05$, ${ }^{* *} \mathrm{p}<0.01,{ }^{* * *} \mathrm{p}<0.001$. 


\section{A. Appendix}

TABLE A.1: DiD Estimates of Introducing/Abolishing Mandatory Internships on Individual Characteristics (Threshold II: 60/40, Sample I)

\begin{tabular}{|c|c|c|c|c|}
\hline \multirow{3}{*}{$\begin{array}{l}\text { Comparison group: } \\
\text { Controls: }\end{array}$} & \multicolumn{2}{|c|}{$\begin{array}{c}\text { Departments } \\
\text { without a change in } \\
\text { mandatory internship }\end{array}$} & \multicolumn{2}{|c|}{$\begin{array}{c}\text { Departments } \\
\text { with/without a } \\
\text { mandatory internship }\end{array}$} \\
\hline & No & Yes & No & Yes \\
\hline & $(1)$ & $(2)$ & $(3)$ & $(4)$ \\
\hline \multicolumn{5}{|c|}{ Panel A. Treatment: Introduction of a mandatory internship } \\
\hline Mother has upper sec. high school degree & $\begin{array}{c}0.048 \\
(0.065)\end{array}$ & $\begin{array}{c}-0.061 \\
(0.081)\end{array}$ & $\begin{array}{c}0.036 \\
(0.068)\end{array}$ & $\begin{array}{l}-0.058 \\
(0.095)\end{array}$ \\
\hline Father has upper sec. high school degree & $\begin{array}{c}0.015 \\
(0.067)\end{array}$ & $\begin{array}{c}0.071 \\
(0.084)\end{array}$ & $\begin{array}{c}0.021 \\
(0.072)\end{array}$ & $\begin{array}{l}0.03 \\
(0.1)\end{array}$ \\
\hline Labor market orientation & $\begin{array}{c}0.023 \\
(0.164)\end{array}$ & $\begin{array}{l}-0.223 \\
(0.207)\end{array}$ & $\begin{array}{l}-0.026 \\
(0.177)\end{array}$ & $\begin{array}{l}-0.383 \\
(0.246)\end{array}$ \\
\hline Final high school grade & $\begin{array}{c}0.474 \\
(0.827)\end{array}$ & $\begin{array}{l}-0.503 \\
(0.940)\end{array}$ & $\begin{array}{c}0.415 \\
(0.899)\end{array}$ & $\begin{array}{l}-1.303 \\
(1.128)\end{array}$ \\
\hline $\mathrm{N}$ & 1,952 & 1,952 & 1,054 & 1,054 \\
\hline \multicolumn{5}{|c|}{ Panel B. Treatment: Abolishment of a mandatory internship } \\
\hline Mother has upper sec. high school degree & $\begin{array}{c}0.097 \\
(0.078)\end{array}$ & $\begin{array}{c}0.15 \\
(0.094)\end{array}$ & $\begin{array}{c}0.099 \\
(0.082)\end{array}$ & $\begin{array}{c}0.163 \\
(0.104)\end{array}$ \\
\hline Father has upper sec. high school degree & $\begin{array}{c}0.01 \\
(0.081)\end{array}$ & $\begin{array}{c}0.03 \\
(0.098)\end{array}$ & $\begin{array}{l}-0.002 \\
(0.083)\end{array}$ & $\begin{array}{c}0.051 \\
(0.107)\end{array}$ \\
\hline Labor market orientation & $\begin{array}{c}0.142 \\
(0.196)\end{array}$ & $\begin{array}{l}0.375 \\
(0.24)\end{array}$ & $\begin{array}{c}0.183 \\
(0.203)\end{array}$ & $\begin{array}{c}0.52^{*} \\
(0.262)\end{array}$ \\
\hline Final high school grade & $\begin{array}{l}-0.113 \\
(0.986)\end{array}$ & $\begin{array}{l}-0.081 \\
(1.09)\end{array}$ & $\begin{array}{l}-0.085 \\
(1.022)\end{array}$ & $\begin{array}{c}-0.551 \\
(1.193)\end{array}$ \\
\hline $\mathrm{N}$ & 1,851 & 1,851 & 1,087 & 1,087 \\
\hline
\end{tabular}

Note: Estimates from DiD, based on threshold II (60/40) definition of treatment. Standard errors in parentheses. No control variables in columns (1) and (3). In columns (2) and (4), the set of control variables comprises gender, year of birth FE, area of study FE, university FE, degree type FE, university type, high school degree type mother and father FE, apprenticeship, high school grade, and degree of labor market orientation. Each row's dependent variable is omitted from the set of controls variables. Panel A: The models in columns (1) and (2) comprise all individuals from rows 1, 3 and 4 of Table 5, for whom the outcome variable is not missing. The models in columns (3) and (4) comprise individuals only from rows 1 and 3. Panel B: The models in columns (1) and (2) comprise all individuals from rows 2, 3 and 4 of Table 5, for whom the outcome variable is not missing. The models in columns (3) and (4) comprise individuals only from rows 2 and 4 . For alternative threshold definitions, see Tables 8 and A.2. ${ }^{+} \mathrm{p}<0.10,{ }^{*} \mathrm{p}<0.05,{ }^{* *} \mathrm{p}<0.01,{ }^{* * *} \mathrm{p}<0.001$. 
TABLE A.2: DiD Estimates of Introducing/Abolishing Mandatory Internships on Individual Characteristics (Threshold III: 70/30, Sample I)

\begin{tabular}{|c|c|c|c|c|}
\hline Comparison group: & \multicolumn{2}{|c|}{$\begin{array}{c}\text { Departments } \\
\text { without a change in } \\
\text { mandatory internship }\end{array}$} & \multicolumn{2}{|c|}{$\begin{array}{c}\text { Departments } \\
\text { with/without a } \\
\text { mandatory internship }\end{array}$} \\
\hline \multirow[t]{2}{*}{ Controls: } & No & Yes & No & Yes \\
\hline & (1) & (2) & (3) & (4) \\
\hline
\end{tabular}

Panel A. Treatment: Introduction of a mandatory internship

$\begin{array}{lcccc}\text { Mother has upper sec. high school degree } & 0.003 & -0.093 & 0.017 & -0.138 \\ & (0.082) & (0.115) & (0.085) & (0.132) \\ \text { Father has upper sec. high school degree } & 0.067 & 0.145 & 0.097 & 0.061 \\ & (0.084) & (0.118) & (0.089) & (0.139) \\ \text { Labor market orientation } & 0.1 & -0.382 & 0.018 & -0.607+ \\ & (0.205) & (0.292) & (0.219) & (0.344) \\ \text { Final high school grade } & 0.555 & -0.293 & 0.606 & 0.008 \\ & (1.041) & (1.339) & (1.117) & (1.592) \\ \mathrm{N} & 1,668 & 1,668 & 835 & 835\end{array}$

Panel B. Treatment: Abolishment of a mandatory internship

$\begin{array}{lllll}\text { Mother: high school degree } & -0.008 & 0.016 & -0.022 & 0.104\end{array}$

$\begin{array}{lllll}\text { Father: high school degree } & -0.014 & 0.051 & -0.041 & 0.105\end{array}$

$\begin{array}{lcccc}\text { Labor market orientation } & 0.796 & 0.753 & 0.857+ & 0.903+ \\ & (0.493) & (0.52) & (0.495) & (0.539) \\ \text { High school grade } & 0.881 & 0.527 & 0.799 & 0.347 \\ & (2.484) & (2.368) & (2.499) & (2.405) \\ \mathrm{N} & 1,523 & 1,523 & 894 & 894\end{array}$

Note: Estimates from DiD, based on threshold III (70/30) definition of treatment. Standard errors in parentheses. No control variables in columns (1) and (3). In columns (2) and (4), the set of control variables comprises gender, year of birth FE, area of study FE, university FE, degree type FE, university type, high school degree type mother and father FE, apprenticeship, high school grade, and degree of labor market orientation. Each row's dependent variable is omitted from the set of controls variables. Panel A: The models in columns (1) and (2) comprise all individuals from rows 1, 3 and 4 of Table 5, for whom the outcome variable is not missing. The models in columns (3) and (4) comprise individuals only from rows 1 and 3. Panel B: The models in columns (1) and (2) comprise all individuals from rows 2, 3 and 4 of Table 5, for whom the outcome variable is not missing. The models in columns (3) and (4) comprise individuals only from rows 2 and 4 . For alternative threshold definitions, see Tables 8 and A.1. ${ }^{+} \mathrm{p}<0.10,{ }^{*} \mathrm{p}<0.05,{ }^{* *} \mathrm{p}<0.01,{ }^{* * *} \mathrm{p}<0.001$. 
TABle A.3: Classification of Areas of Study into Strong and Weak Labor Market Orientation

\begin{tabular}{ll}
\hline Strong LM orientation & Weak LM orientation \\
\hline administrative studies & ancient/classic philology, modern Greek \\
agricultural sciences & area studies \\
architecture and interior design & arts, general art history \\
biology & catholic theology/religious education \\
chemical science & composition and design \\
civil engineering & cultural studies/cultural sciences \\
computer science & English studies, American studies \\
dentistry/dental medicine & extra-European linguistic and cultural studies \\
economics & film studies \\
electrical engineering & fine arts \\
engineering management & comparative literary and linguistic sciences \\
food and beverage technology & general cultural studies \\
forestry, forest and wood management & general economic and social science \\
general engineering & general linguistics and philology \\
geomatic/geospatial engineering & geography \\
geosciences (without geography) & German philology and studies \\
healthcare science & history \\
human medicine & library science, documentation, communication \\
jurisprudence/law & music, musicology \\
landscape conservation, - architecture & education \\
mathematics, natural sciences & performing arts, theater studies \\
mechanical engineering, process engineering & philosophy \\
mining and metallurgy & political sciences \\
nautical science / navigation & protestant theology/religious education \\
pharmacy & psychology \\
physics, astronomy & Romance philology and studies \\
social pedagogy & Slavonic, Baltic, Finno-Ugrian studies \\
spatial planning & social sciences \\
teletraffic engineering & special education \\
trophology, nutritional and domestic science & sport science \\
veterinary medicine & \\
\hline & \\
\hline
\end{tabular}

Note: Based on Scarletti (2009). 
TABle A.4: DiD Estimates of Introducing Mandatory Internships on Quality Indicators (Threshold II: 60/40, Sample I)

\begin{tabular}{|c|c|c|c|c|}
\hline Comparison group: & \multicolumn{2}{|c|}{$\begin{array}{l}\text { Departments without a change } \\
\text { in mandatory internship }\end{array}$} & \multicolumn{2}{|c|}{$\begin{array}{l}\text { Departments without a } \\
\text { mandatory internship }\end{array}$} \\
\hline Controls: & No & Yes & No & Yes \\
\hline & (1) & $(2)$ & (3) & (4) \\
\hline
\end{tabular}

Treatment: Introduction of a mandatory internship

Overall quality of education:

Structure of the study program

State-of-the-art methods taught

Up-to-date education $^{\mathrm{a}}$

Educational media and infrastructure:

Availability of literature in the library

Access to IT services (internet, databases)

Laboratory facilities

\section{Training:}

Oral presentation training

Writing skills training

Training in foreign languages ${ }^{b}$

\section{Career Counseling:}

Help in finding a job and starting a career

Availability of career counseling

Provision of career orientation events

$\begin{array}{cccc}-0.153 & -0.143 & -0.204 & -0.164 \\ (0.128) & (0.152) & (0.137) & (0.173) \\ -0.118 & 0.114 & -0.105 & 0.084 \\ (0.125) & (0.155) & (0.133) & (0.182) \\ -0.168 & -0.039 & -0.261+ & -0.104 \\ (0.143) & (0.174) & (0.153) & (0.204)\end{array}$

0.186

0.105

0.118

0.097

$(0.149)$

$(0.181)$

0.04

$(0.163)$

(0.219)

0.028

$(0.159)$

$-0.08$

0.094

0.229

(0.13)

$-0.087$

(0.161)

$(0.206)$

(0.142)

(0.191)

$-0.019$

0.12

(0.178)

$(0.257)$

$\begin{array}{cccc}-0.316+ & -0.078 & -0.333+ & -0.04 \\ (0.172) & (0.213) & (0.179) & (0.251) \\ -0.228 & -0.408^{*} & -0.269 & -0.408+ \\ (0.164) & (0.206) & (0.176) & (0.239) \\ -0.092 & 0.036 & -0.016 & 0.174 \\ (0.165) & (0.195 & (0.176) & (0.237)\end{array}$

$(0.165)$

$(0.195$

$(0.176)$

(0.237)

0.015

0.049

0.076

$-0.07$

(0.226)

(0.156)

(0.192)

$-0.007$

0.142

(0.168)

0.138

(0.147)

(0.182)

$-0.119$

$(0.212)$

0.107

0.161

$(0.158)$

0.018

$(0.146)$

$-0.025$

(0.154)

\begin{tabular}{lllll}
\hline $\mathrm{N}$ & 1,788 & 1,788 & 954 & 954 \\
\hline
\end{tabular}

Note: Estimates from DiD, based on threshold II (60/40) definition of treatment. Standard errors in parentheses. No control variables in columns (1) and (3). In columns (2) and (4), the set of control variables comprises gender, year of birth FE, area of study FE, university FE, degree type FE, university type, high school degree type mother and father FE, apprenticeship, high school grade, and degree of labor market orientation. The models in columns (1) and (2) comprise all individuals from rows 1, 3 and 4 of Table 5, for whom the outcome variable is not missing. The models in columns (3) and (4) comprise individuals only from rows 1 and $3{ }^{a}$ The variable measures the actuality of education with respect to current job requirements. ${ }^{b}$ The variable measures subject- or job-specific training in foreign languages. ${ }^{c}$ Sample size $N=1,723 .{ }^{d}$ Sample size $N=1,108$. $+\mathrm{p}<0.10,{ }^{*} \mathrm{p}<0.05,{ }^{* *} \mathrm{p}<0.01,{ }^{* * *} \mathrm{p}<0.001$. 
TABle A.5: DiD Estimates of Abolishing Mandatory Internships on Quality Indicators (Threshold II: 60/40, Sample I)

\begin{tabular}{|c|c|c|c|c|}
\hline Comparison group: & \multicolumn{2}{|c|}{$\begin{array}{l}\text { Departments without a change } \\
\text { in mandatory internship }\end{array}$} & \multicolumn{2}{|c|}{$\begin{array}{l}\text { Departments without a } \\
\text { mandatory internship }\end{array}$} \\
\hline Controls: & No & Yes & No & Yes \\
\hline & (1) & $(2)$ & (3) & $(4)$ \\
\hline
\end{tabular}

Treatment: Abolishment of a mandatory internship

Overall quality of education:

Structure of the study program

State-of-the-art methods taught

Up-to-date education $^{\mathrm{a}}$

Educational media and infrastructure:

Availability of literature in the library

Access to IT services (internet, databases)

Laboratory facilities

Training:

Oral presentation training

Writing skills training

Training in foreign languages ${ }^{b}$

\section{Career Counseling:}

Help in finding a job and starting a career

Availability of career counseling

Provision of career orientation events

$\begin{array}{cccc}0.032 & 0.203 & 0.083 & 0.181 \\ (0.147) & (0.17) & (0.151) & (0.188) \\ 0.209 & 0.038 & 0.2 & 0.04 \\ (0.143) & (0.174) & (0.15) & (0.19) \\ -0.01 & 0.037 & 0.074 & 0.082 \\ (0.165) & (0.195) & (0.171) & (0.219)\end{array}$

0.015

$(0.17)$

0.011

0.061

0.107

$-0.005$

$(0.148)$

0.096

$(0.173)$

$(0.205)$

$(0.173)$

(0.219)

0.107

$-0.057$

0.024

(0.174)

(0.155)

(0.188)

$-0.213$

(0.203)

0.07

(0.175)

$-0.343$

$(0.217)$

$\begin{array}{cccc}0.125 & 0.11 & 0.148 & -0.06 \\ (0.199) & (0.24) & (0.211) & (0.262) \\ -0.049 & -0.05 & -0.019 & -0.018 \\ (0.188) & (0.231) & (0.196) & (0.256) \\ 0.248 & 0.122 & 0.197 & 0.015 \\ (0.194) & (0.221) & (0.199) & (0.233)\end{array}$

(0.194)

(0.221)

(0.199)

(0.233)

$\begin{array}{cccc}-0.175 & -0.101 & -0.066 & 0.024 \\ (0.183) & (0.22) & (0.19) & (0.243) \\ -0.344^{*} & -0.117 & -0.244 & 0.016 \\ (0.171) & (0.208) & (0.177) & (0.228) \\ 0.014 & 0.135 & 0.127 & 0.333 \\ (0.168) & (0.206) & (0.175) & (0.224)\end{array}$

\begin{tabular}{lllll}
\hline $\mathrm{N}$ & 1,715 & 1,715 & 1014 & 1014
\end{tabular}

Note: Estimates from DiD, based on threshold II (60/40) definition of treatment. Standard errors in parentheses. No control variables in columns (1) and (3). In columns (2) and (4), the set of control variables comprises gender, year of birth FE, area of study FE, university FE, degree type FE, university type, high school degree type mother and father FE, apprenticeship, high school grade, and degree of labor market orientation. The models in columns (1) and (2) comprise all individuals from rows 2, 3 and 4 of Table 5, for whom the outcome variable is not missing. The models in columns (3) and (4) comprise individuals only from rows 2 and $4 .{ }^{a}$ The variable measures the actuality of education with respect to current job requirements. ${ }^{b}$ The variable measures subject- or job-specific training in foreign languages. ${ }^{c}$ Sample size $N=1,723 .{ }^{d}$ Sample size $N=1,108$. ${ }^{+} \mathrm{p}<0.10,{ }^{*} \mathrm{p}<0.05,{ }^{* *} \mathrm{p}<0.01,{ }^{* * *} \mathrm{p}<0.001$. 
TABLE A.6: DiD Estimates of Introducing Mandatory Internships on Quality Indicators (Threshold III: 70/30, Sample I)

\begin{tabular}{|c|c|c|c|c|}
\hline Comparison group: & \multicolumn{2}{|c|}{$\begin{array}{l}\text { Departments without a change } \\
\text { in mandatory internship }\end{array}$} & \multicolumn{2}{|c|}{$\begin{array}{l}\text { Departments without a } \\
\text { mandatory internship }\end{array}$} \\
\hline Controls: & No & Yes & No & Yes \\
\hline & (1) & $(2)$ & (3) & (4) \\
\hline
\end{tabular}

Treatment: Introduction of a mandatory internship

Overall quality of education:

Structure of the study program

State-of-the-art methods taught

Up-to-date education $^{\mathrm{a}}$

Educational media and infrastructure:

Availability of literature in the library

Access to IT services (internet, databases)

Laboratory facilities

Training:

Oral presentation training

Writing skills training

Training in foreign languages ${ }^{b}$

\section{Career Counseling:}

Help in finding a job and starting a career

Availability of career counseling

Provision of career orientation events

$\begin{array}{cccc}0.059 & -0.104 & 0.036 & -0.156 \\ (0.16) & (0.216) & (0.168) & (0.245) \\ -0.159 & 0.204 & -0.139 & 0.144 \\ (0.155) & (0.219) & (163) & (0.257) \\ -0.187 & 0.149 & -0.238 & 0.096 \\ (0.178) & (0.247) & (0.19) & (0.288)\end{array}$

0.263

$(0.189)$

0.093

(0.163)

$-0.314$

(0.201)

$-0.409+$

(0.219)

0.019

(0.208)

0.085

(0.21)

$-0.386+$
0.439

(0.309)

0.323

(0.265)

0.057

(0.356)

$-0.121$

(0.365)

$-0.067$

(0.342)

$0.657+$

(0.34)
0.188

(0.258)

0.106

(0.223)

$-0.147$

(0.278)

$-0.203$

(0.304)

$-0.313$

$(0.295)$

0.424

(0.276)

0.226

(0.273)

0.182

$(0.258)$

0.12

(0.257)
0.18

(0.206)

0.163

(0.174)

$-0.201$

(0.223)

(0.225)

$-0.012$

$(0.22)$

0.147

(0.222)

0.128

(0.205)

0.035

(0.196)

0.042

(0.19)

0.128

(0.182)

\begin{tabular}{llllll}
\hline $\mathrm{N}$ & 1,531 & 1,531 & 758 & 758 \\
\hline
\end{tabular}

758

0.101

(0.323)

0.196

(0.36

$-0.013$

(0.302)

Note: Estimates from DiD, based on threshold III (70/30) definition of treatment. Standard errors in parentheses. No control variables in columns (1) and (3). In columns (2) and (4), the set of control variables comprises gender, year of birth FE, area of study FE, university FE, degree type FE, university type, high school degree type mother and father FE, apprenticeship, high school grade, and degree of labor market orientation. The models in columns (1) and (2) comprise all individuals from rows 1, 3 and 4 of Table 5, for whom the outcome variable is not missing. The models in columns (3) and (4) comprise individuals only from rows 1 and $3 .{ }^{a}$ The variable measures the actuality of education with respect to current job requirements. ${ }^{b}$ The variable measures subject- or job-specific training in foreign languages. ${ }^{c}$ Sample size $N=1,723 .{ }^{d}$ Sample size $N=1,108$. $+\mathrm{p}<0.10,{ }^{*} \mathrm{p}<0.05,{ }^{* *} \mathrm{p}<0.01,{ }^{* * *} \mathrm{p}<0.001$. 
TABle A.7: DiD Estimates of Abolishing Mandatory Internships on Quality Indicators (Threshold III: 70/30, Sample I)

\begin{tabular}{|c|c|c|c|c|}
\hline Comparison group: & \multicolumn{2}{|c|}{$\begin{array}{l}\text { Departments without a change } \\
\text { in mandatory internship }\end{array}$} & \multicolumn{2}{|c|}{$\begin{array}{l}\text { Departments without a } \\
\text { mandatory internship }\end{array}$} \\
\hline Controls: & No & Yes & No & Yes \\
\hline & (1) & $(2)$ & (3) & $(4)$ \\
\hline
\end{tabular}

Treatment: Abolishment of a mandatory internship

Overall quality of education:

Structure of the study program

$\begin{array}{cccc}0.382 & 0.600 & 0.402 & 0.516 \\ (0.371) & (0.371) & (0.371) & (0.384) \\ 0.708^{*} & 0.813^{*} & 0.693+ & 0.852^{*} \\ (0.355) & (0.372) & (0.360) & (0.380) \\ 0.233 & 0.565 & 0.272 & 0.687 \\ (0.408) & (0.418) & (0.408) & (0.436)\end{array}$

Educational media and infrastructure:

State-of-the-art methods taught

Availability of literature in the library

0.205

0.271

0.262

0.374

Access to IT services (internet, databases)

$(0.428)$

(0.441)

$(0.422)$

$(0.443)$

0.106

0.424

0.054

0.503

Laboratory facilities

$(0.366)$

(0.372)

$(0.373)$

$(0.38)$

$-0.152$

$-0.308$

$-0.220$

$-0.219$

(0.403)

(0.398)

(0.393)

(0.398)

Training:

Oral presentation training

$\begin{array}{cccc}0.517 & 0.464 & 0.503 & 0.460 \\ (0.499) & (0.514) & (0.511) & (0.522) \\ 0.354 & 0.025 & 0.376 & 0.019 \\ (0.74) & (0.504) & (0.474) & (0.525) \\ 0.641 & 0.764 & 0.605 & 0.698 \\ (0.488) & (0.474) & (0.484) & (0.465)\end{array}$

Career Counseling:

Writing skills training

Training in foreign languages ${ }^{b}$

$$
\text { (0.488) }
$$

Help in finding a job and starting a career

$\begin{array}{cccc}0.09 & 0.207 & 0.160 & 0.523 \\ (0.442) & (0.468) & (0.447) & (0.486) \\ -0.314 & -0.021 & -0.276 & 0.037 \\ (0.422) & (0.444) & (0.424) & (0.452) \\ 0.244 & 0.482 & 0.309 & 0.516 \\ (0.415) & (0.439) & (0.421) & (0.450)\end{array}$

$\mathrm{N}$

1,407

1,407

829

829

Note: Estimates from DiD, based on threshold III (70/30) definition of treatment. Standard errors in parentheses. No control variables in columns (1) and (3). In columns (2) and (4), the set of control variables comprises gender, year of birth FE, area of study FE, university FE, degree type FE, university type, high school degree type mother and father FE, apprenticeship, high school grade, and degree of labor market orientation. The models in columns (1) and (2) comprise all individuals from rows 2, 3 and 4 of Table 5, for whom the outcome variable is not missing. The models in columns (3) and (4) comprise individuals only from rows 2 and $4 .{ }^{a}$ The variable measures the actuality of education with respect to current job requirements. ${ }^{b}$ The variable measures subject- or job-specific training in foreign languages. ${ }^{c}$ Sample size $N=1,723 .{ }^{d}$ Sample size $N=1,108$. ${ }^{+} \mathrm{p}<0.10,{ }^{*} \mathrm{p}<0.05,{ }^{* *} \mathrm{p}<0.01,{ }^{* * *} \mathrm{p}<0.001$. 
Figure A.1: Students' Evaluation of Study Related Aspects

(A) Overall Quality of Education
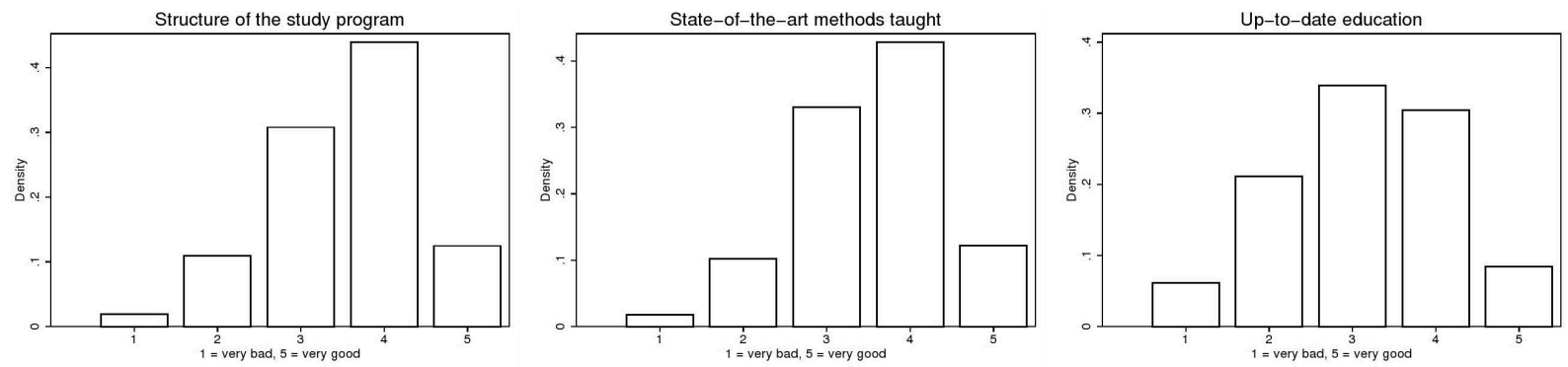

(B) Educational Media and Infrastructure
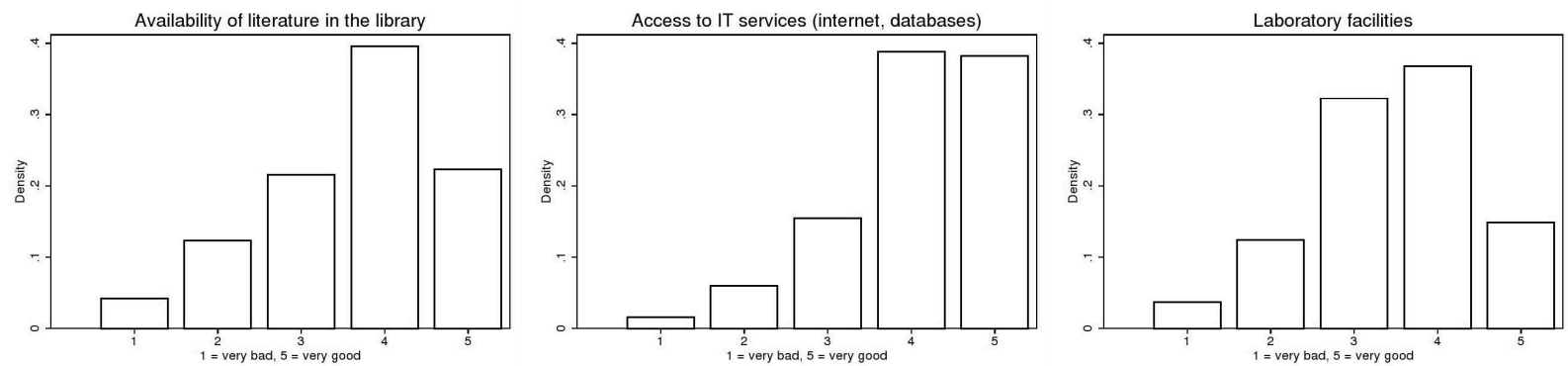

(c) Training
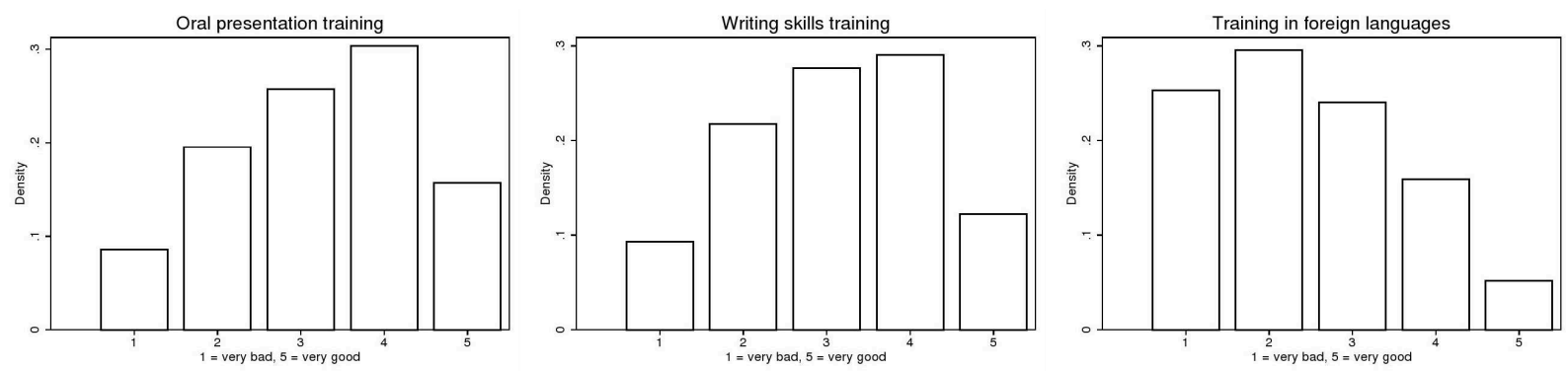

(D) Career Counseling
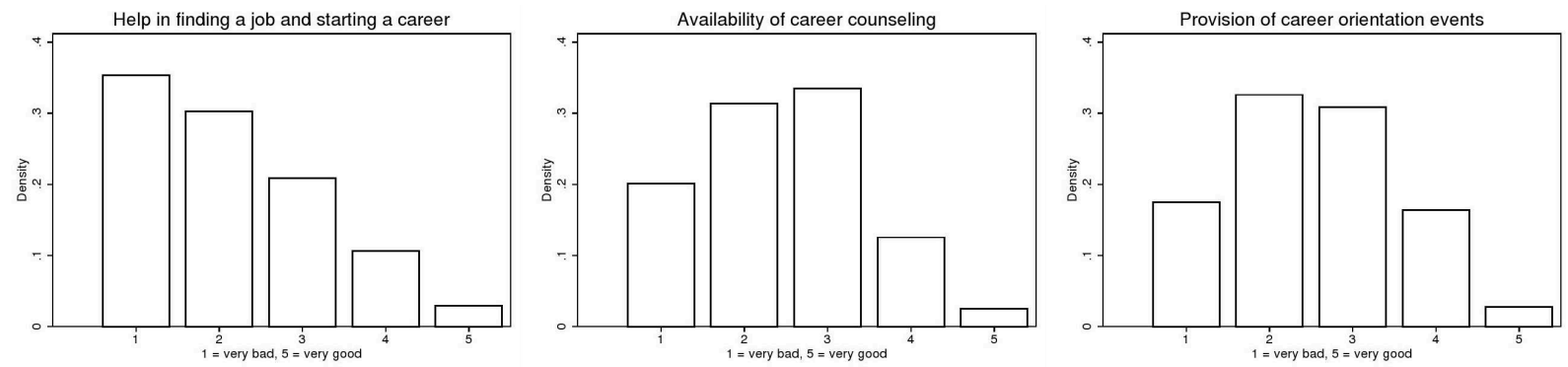

Note: The corresponding questionnaire item reads "How do you evaluate the following aspects of your completed studies?" Respondents are then asked to answer on a scale from 1 ("very bad") to 5 ("very good"). 